U.S. Anmy Coast. Eng. Res. Otr. Tech. Repa CERC.90-15
Sep 1990

\title{
FUNCTIONAL DESIGN OF BREAKWATERS FOR SHORE PROTECTION: EMPIRICAL METHODS
}

\author{
by \\ Julie Dean Rosati \\ Coastal Engineering Research Center \\ DEPARTMENT OF THE ARMY \\ Waterways Experiment Station, Corps of Engineers \\ 3909 Halls Ferry Road, Vicksburg, Mississippi 39180-6199
}
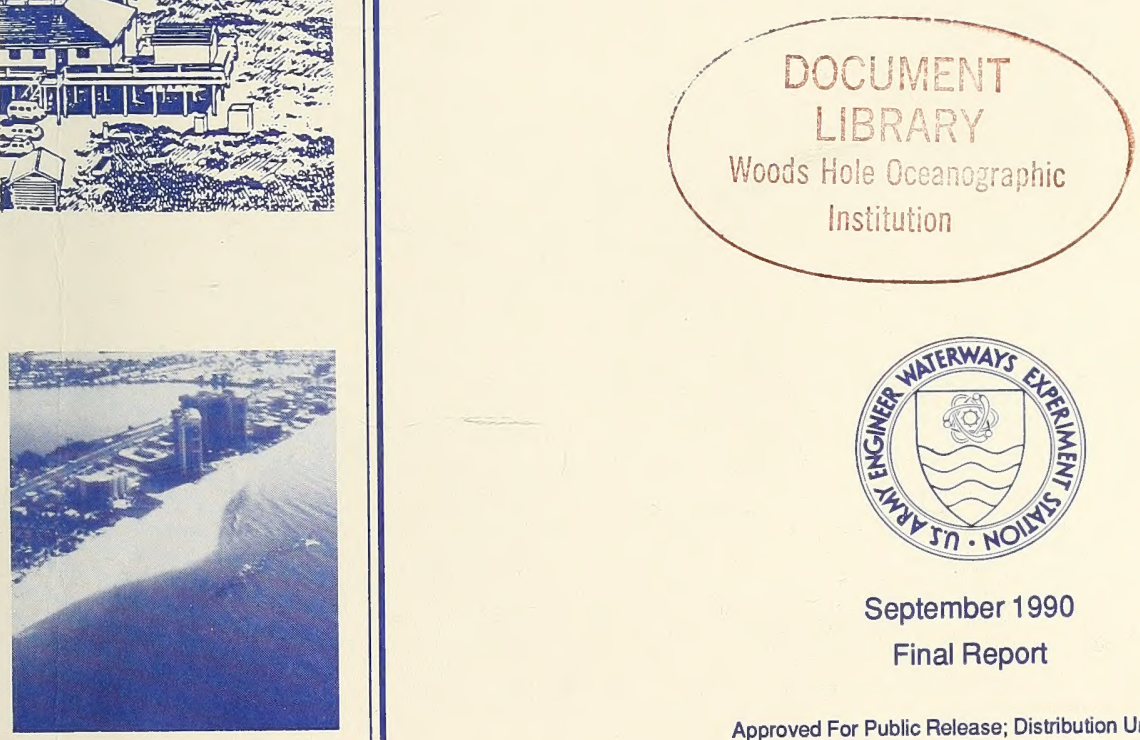

September 1990

Final Report

Approved For Public Release; Distribution Unlimited

Prepared for DEPARTMENT OF THE ARMY

US Army Corps of Engineers

Washington, DC 20314-1000

Under Civil Works Research Work Unit 32535 
Destroy this report when no longer needed. Do not return it to the originator.

The findings in this report are not to be construed as an official Department of the Army position unless so designated by other authorized documents.

The contents of this report are not to be used for advertising, publication, or promotional purposes.

Citation of trade names does not constitute an official endorsement or approval of the use of such commercial products. 
Unclassified

SECURITY CLASSIFICATION OF THIS PAGE

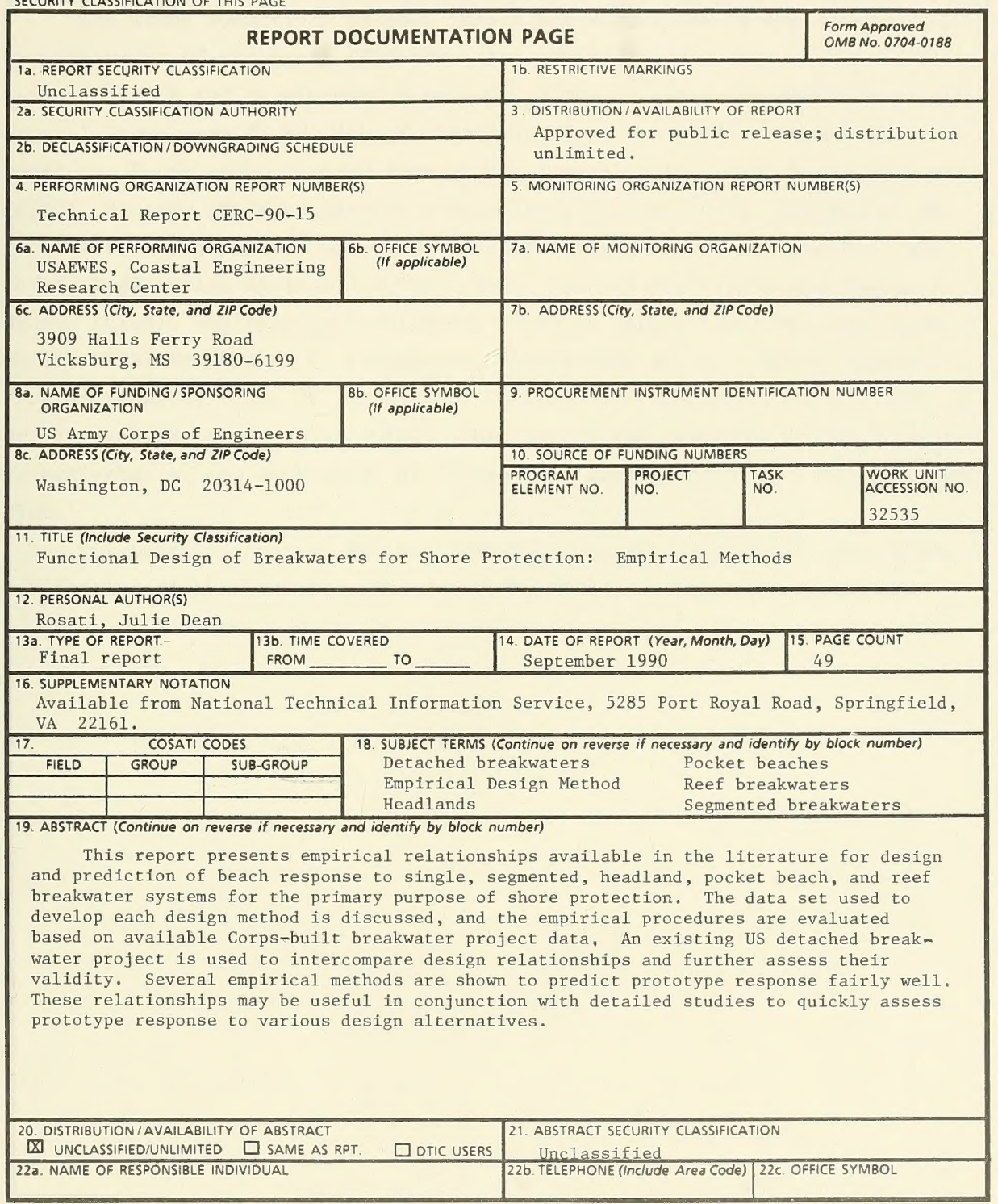




$$
\square
$$


The study summarized in this report was authorized by the Headquarters, US Army Corps of Engineers (HQUSACE), and performed as a part of the Civil Works Research and Development Work Unit 32535, "Engineering Performance of Coastal Structures." Mr. John H. Lockhart, Jr., was HQUSACE Technical Monitor. Funds were provided through the Coastal Engineering Research Center (CERC), US Army Engineer Waterways Experiment Station (WES), Vicksburg, MS.

Work was performed under the general supervision of Dr. Yen-hsi Chu, Chief, Engineering Application Unit (EAU), Coastal Structures and Evaluation Branch (CSEB), Engineering Development Division (EDD), CERC; Ms. Joan Pope, Chief, CSEB; Mr. Thomas W. Richardson, Chief, EDD; Dr. C. Linwood Vincent, Program Manager, CERC; Mr. Charles C. Calhoun, Jr., Assistant Chief, CERC; and Dr. James R. Houston, Chief, CERC. This report was prepared by the Principal Investigator of the work unit, Ms. Julie Dean Rosati, Hydraulic Engineer, EAU, CSEB.

COL Larry B. Fulton, EN, was Commander and Director of WES during the publication of this report. Dr. Robert W. Whalin was Technical Director. 
PREFACE . . . . . . . . . . . . . . . . . . . . . . . . . . . Page

LIST OF FIGURES. . . . . . . . . . . . . . . . . . . . . . . . . . 3

PART I: INTRODUCTION . . . . . . . . . . . . . . . . . . . . . . . . . 4

PART II: TECHNIQUES FOR DETACHED BREAKWATER DESIGN . . . . . . . . . . . 7

Overview . . . . . . . . . . . . . . . . . . . . 7

Empirical Relationships . . . . . . . . . . . . . . . . . . . . . . . 8

PART III: ASSESSMENT OF DESIGN TECHNIQUES . . . . . . . . . . . . . . . 28

Introduction . . . . . . . . . . . . . . . . . . . . . . . . 28

Evaluations. . . . . . . . . . . . . . . . . . . . 28

PART IV: SUMMARY AND RECOMMENDATIONS . . . . . . . . . . . . . . . . . . 38

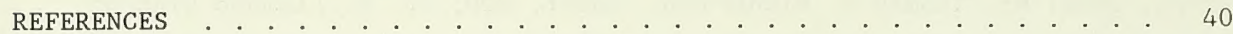

APPENDIX A: NOTATION . . . . . . . . . . . . . . . . . . A1 


\section{LIST OF FIGURES}

No. $\quad \underline{\text { Page }}$

1 Definition of terms used in this report . . . . . . . . . . . . . . . . 9

2 Equilibrium salient formation. . . . . . . . . . . . . . . . . . . . 13

3 Equilibrium tombolo formation . . . . . . . . . . . . . . . . . . . . 13

4 Morphological response as a function of structural parameters . . . . 18

5 Relationship to predict gap erosion for pocket beaches . . . . . . . 20

6 Effect of gap spacing on sand deposition to lee of breakwater . . . . 24

7 Effect of gap spacing on sand deposition for each breakwater gap pair . . . . . . . . . . . . . . . . . . . . 25

8 Effect of gap spacing on sand deposition for gap region . . . . . . . 25

9 Relationship to predict gap erosion for headland structures . . . . . 26

10 Evaluation of morphological relationships . . . . . . . . . . . . . . 30

11 Evaluation of Suh and Dalrymple's (1986) relationship for salient 31

12 Combined evaluation of Harris and Herbich's (1986) and Nir's (1982) relationships . . . . . . . . . . . . . . . . . . . . 32

13 Evaluation of Seiji, Uda, and Tanaka's (1987) limits for gap erosion . . . . . . . . . . . . . . . . . . 32

14 Evaluation of Berenguer and Enriquez' (1988) and Ahrens' relationships for pocket beach gap erosion . . . . . . . . . . . . . . . 33

15 Evaluation of Hallermeier's (1983) relationship for structure design depth . . . . . . . . . . . . . . . . . . . . . . . . . . 34

16 Lakeview Park project parameters as designed with JMC method . . . . 35

17 Lakeview Park project as constructed (Diffraction Energy Method) . . 35 


\section{PART I: INTRODUCTION}

1. The increase in public use of coastal areas during the 20th century and a gradual relative sea level rise in many areas of the world have made beach stabilization a priority for those who use coastal regions. An ideal form of shore protection is one that would allow long-term stabilization of an area in a cost-effective manner, protect upland structures to some degree during storms, and provide an aesthetic recreational area, while avoiding undesirable adjacent beach effects. All forms of shore protection (i.e., groins, breakwaters, seawalls, revetments, bulkheads, beach-fill, etc.) have certain disadvantages; however, the shore-parallel breakwater, placed at the shoreline or offshore and designed either to intercept a portion of longshoremoving sediment or to protect a placed beach-fill, has the potential to perform close to the ideal for many types of coastal environments.

2. Breakwaters provide protection to a length of shoreline by dissipating, reflecting, and diffracting incoming wave energy. Pope (1989) and Dally and Pope (1986) discuss the terms that have evolved to describe the different functional behaviors of the shore-parallel structure. Headland breakwaters are constructed at or very near the original shoreline, designed to promote beach growth out to the structure (tombolo formation) during all or part of the water-level cycle. These structures tend to function as a transmissible groin, intercepting all or a portion of the longshore-moving material. Pocket beach breakwaters are a class of headland breakwaters, used to provide protection to a placed beach-fill that is usually retained in the longshore direction by terminal groins. The protected shoreline may extend partially out towards the structure (termed a salient), or a tombolo may form. Detached breakwaters are constructed at a significant distance offshore of the original shoreline and interact with incoming wave energy to produce a quiescent region landward of the structure. Depending on structural and site parameters (structure length, distance offshore, transmissibility, wave climate, etc.), morphological beach response may be either a salient or tombolo. Reef breakwaters are a type of detached breakwaters constructed with a low crest 
elevation, therefore allowing a significant amount of wave energy into the protected area. The beach response to these types of structures is usually a salient; these structures may be advantageous for sites where the interruption of the horizon by a structure is considered unaesthetic. Unless otherwise noted, reef breakwaters have been grouped with detached breakwaters, and pocket beach breakwaters with headland breakwaters, throughout this report. For projects with relatively short alongshore distances to protect, a single breakwater is often sufficient. For longer length projects, a series of structures may be required to protect the project beach; this series is termed a segmented system.

3. Unlike shore-perpendicular structures (i.e., groins), which impound sediment and ultimately starve downdrift beaches, detached breakwaters can be designed to allow material to pass through the sheltered region, minimizing their impact on adjacent shorelines. Onshore, shore-parallel structures such as seawalls, revetments, and bulkheads are designed to prevent retreat of the landward region they protect and do nothing to reduce erosion of the beach. Beach-fill reduces the storm impacts to upland structures, while providing a recreational beach; however, the quantities of replenishment required for maintenance may be cost-prohibitive. The use of detached or headland breakwaters in combination with beach-fill may provide a cost-effective alternative to beach-fill alone for many coastal regions.

4. Although the breakwater appears to have advantages over the other traditional forms of shore protection mentioned above, use of this form of shore protection has been minimal in the United States. Seventeen detached breakwater projects ( 46 breakwater segments) exist along 9,200 km of the continental US and Hawaiian shorelines. Seventy-one additional segments either are in the early stages of construction or are planned for construction within the next few years by the US Army Corps of Engineers* (Gorecki and Pope in preparation). Comparatively, at least 4,000 detached breakwater segments exist along Japan's 9,400-km coast (Seiji, Uda, Tanaka 1987; Japanese Ministry of Construction (JMC) 1986); 15 segments provide protection to the $300 \mathrm{~km}$ of Israeli Mediterranean shoreline (Goldsmith and Sofer 1983); and

* Personal Communication, 1989, Edward Fulford, Chief, Coastal Planning Section, formerly US Army Engineer District (USAED), Baltimore, Baltimore, MD, and Thomas Bender, Chief, Coastal Engineering Section, USAED, Buffalo, Buffalo, NY. 
80 breakwater segments have recently been constructed on the Danish North Sea coast (Laustrup 1988). Shore-parallel structures for shore protection have also been used in Spain (Berenguer and Enriquez 1988) and Singapore (Silvester and Ho 1972; Chew, Wong, and Chin 1974) and are being evaluated for a major coast protection scheme in Negombo, Sri Lanka (Danish Hydraulic Institute 1988). The documented performance of these structures in Japan and Israel demonstrates that this type of shore protection is both effective and versatile, successfully performing in low to moderate wave energy environments with sediment ranging from fine sand to pebbles.

5. A primary reason breakwaters have been under-utilized in the United States is the lack of functional design guidance. Techniques to predict beach response in the project area and on adjacent shores as a function of structural and site parameters may be unreliable, unproven, cost- and timeintensive, or not readily available to the project designer. Other factors limiting the use of breakwaters in the United States include the high cost of water-based construction (used in most cases for detached breakwaters) and an inability to predict and compensate for structure-related phenomena such as adjacent beach erosion, rip currents, scour at the structure base, and the effects of structural settlement on project performance.

6. The purpose of this report is to present and evaluate the various empirical breakwater design methods available to the project engineer. In Part II, the major categories of design techniques available are briefly presented, and empirical design relationships available in the literature are discussed with a common definition of terms. The methods described in Part II are evaluated in Part III using data available from several us projects. In Part IV, the empirical design techniques demonstrated to predict prototype response to detached breakwater systems are recommended for use by field engineers. Variables used throughout the report are defined in Appendix A. 


\section{Overview}

7. Techniques for designing detached breakwater systems can be classified into three categories: models, which numerically or physically simulate coastal response to a proposed design; empirical methods, which relate proposed project variables to beach response based on observed prototype and model results; and prototype assessment, in which a version of the final design is constructed, evaluated, and refined in the field. Each design classification has inherent advantages and disadvantages.

8. Numerical and physical models are powerful tools that can give detailed information about coastal response to a particular design; however, a detailed prototype data set is usually required for calibration, verification, and simulation. The shoreline response model GENESIS (GENEralized SImulation model for Shoreline Change) is designed to simulate beach response to a variety of erosion control structures and was successfully used to simulate shoreline change at the Lakeview Park breakwater project (Hanson and Kraus 1989). Physical model tests can be expensive and time-consuming, and numerical model simulations can mislead the designer through model instability or accurate solutions to inaccurate input conditions. Empirical relationships are quick, inexpensive methods for evaluating beach response to a proposed design; however, often the relationships have oversimplified design variables and expected prototype response. Empirical relationships rarely are able to predict complicated structure-induced phenomena such as the formation of rip currents in the vicinity of the project, or the extent of project influence on adjacent beaches. Where feasible, a prototype assessment of a proposed design is the best method for refinement of the final design. However, a prototype evaluation may be prohibitively expensive, and the construction of a poor design alternative may make it publicly and politically difficult for funding of the final project.

9. To ensure a successful project, the iterative use of various design techniques is recommended. Dally and Pope (1986) suggest a three-phase design process: first, a desk-top study employing various empirical relationships to identify design alternatives; second, either a physical or numerical model 
study to assess and refine alternatives; and finally, if time and funding allow, a prototype test to verify and adjust the preliminary design. Initial use of empirical design methods can also provide a means of assessing model performance. Numerical and physical models, once calibrated and verified, can be used to extend and improve empirical relationships. Prototype assessment of a design alternative can provide data for refinement of empirical relationships and model calibration/verification.

10. The design methods that will be presented and evaluated herein are various empirical relationships for iterative use throughout the project design. These relationships include those that have been used to design US and foreign detached breakwater projects, and those recently developed through prototype and physical model evaluation.

\section{Empirica1 Relationships}

\section{Introduction}

11. Prior to utilizing techniques for any type of structure design, the functional intent of the project must be well-defined. Parameters such as the length of shoreline to be protected, design beach width, and acceptable adjacent beach erosion/accretion should be delimited. A breakwater project can be designed in segments, to protect a long length of shoreline, for salient or tombolo formation, or both. In the case of a site with a significant longshore transport rate adjacent to beaches that cannot tolerate much project-induced beach change, the design beach response should be a salient. A salient allows littoral movement of material to continue shoreward of the structures, minimizing project impacts on adjacent shores. If impacts to adjacent beaches are not of concern, the breakwater system could be designed for tombolo formation, maximizing project beach accretion. A common nomenclature for all relationships will be used throughout this report and is presented in Figure 1. All variables used throughout the report are defined in Appendix A.

12. The empirical relationships presented herein are generally organized from the simpler to more complex design techniques and comprise a review of all studies that have recommended empirical relationships or methods for the design of breakwater systems. A general review of detached breakwater 


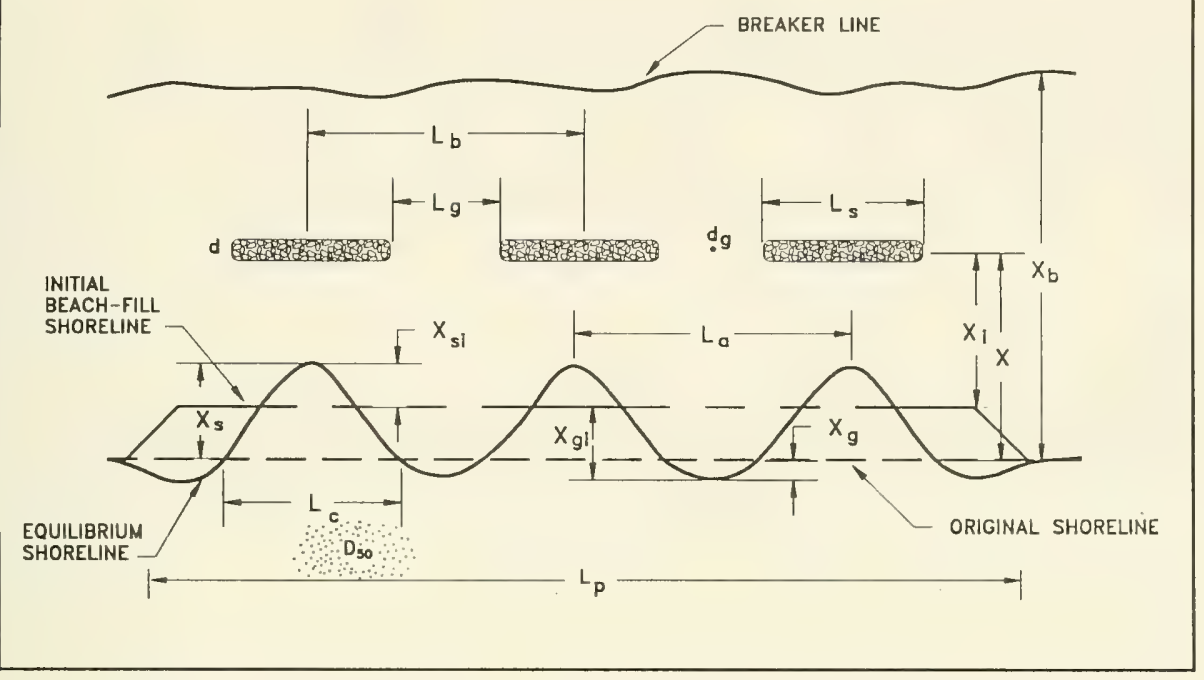

Figure 1. Definition of terms used in this report

references can be found in Lesnick (1979).

13. The most-investigated effect of detached breakwaters is the relationship between project accretion, in particular, morphological response (salient or tombolo), and structural parameters. Similar simple relationships between structure length and distance offshore have been proposed by various researchers.

\section{Inman and Frautschy (1966)}

14. Based on observations of beach response at the 434-m-1ong single detached breakwater at Venice in Santa Monica, CA, Inman and Frautschy (1966) observed that pronounced accretion did not occur for the following condition:

$$
\begin{aligned}
& \frac{L_{s}}{X} \leq 0.17-0.33 \text { pronounced accretion did } \\
& \text { not occur }
\end{aligned}
$$

where $L_{\mathrm{s}}$ is the breakwater segment length, and $X$ is the breakwater segment 
distance from the original shoreline.

Nir (1982)

15. Based on project performance of 12 breakwaters on the Israeli coast, Nir (1982) concluded that accretion is very low or does not occur at all if the segment length to offshore distance ratio has a value of 0.5 or less:

$$
\frac{L_{s}}{X} \leq 0.5 \text { nondepositional condition }
$$

Assuming that the planform of the tombolo/salient formed a trapezoid, Nir calculated the area and volume of each spit out to the depth of structure. Dividing the volume by the area, Nir calculated the average sand thickness in the tombolo/salient $z_{\mathrm{s}}$ and related it to the structure-distance ratio as follows (note that the equation is dimensionally inconsistent):

$$
z_{s}(m)=1.786-0.809\left(\frac{X}{L_{s}}\right)
$$

The relationship was developed from prototype data with $X / L_{s}$ values ranging from 0.38 to 2.0 , resulting in sand thicknesses ranging from approximately 0.3 to $1.7 \mathrm{~m}$. Seven out of the twelve structures developed tombolos. Beach response for the Israeli breakwaters was observed to reach a mature age about 5 years after construction was completed; adjacent beaches suffered severe erosion during the first 3 to 4 years (or longer) after construction. Gourlay (1981)

16. Gourlay (1981) presents similar relationships based on physical model and field observations. Based on the laboratory studies of Sauvage de St. Mark and Vincent (1955), Adachi, Sawaragi, and Ogo (1959), and Shinohara and Tsubaki (1967), Gourlay reaches the following conclusions for laboratory response to detached breakwaters:

a. Tombolos can form only if the structure is located in the surf zone.

b. Noninterfering diffraction patterns, resulting in two independent current systems (and possibly double tombolo formation), exist for the following structure-distance ratio: 


$$
\frac{L_{s}}{X}>2.0
$$

c. Diffraction patterns interfered and reduced longshore currents for a lower range of the ratio. Beach response was observed to be either a salient if bed load was the dominant transport mechanism (fall velocity parameter, $H_{0} / V T<1.5$, where $H_{0}$ is the deepwater wave height, $V$ is the sediment fall velocity, and $T$ is the wave period), or a more complex feature if suspended load transport dominated $\left(H_{0} / V T>1.5\right)$ :

$$
\frac{L_{s}}{X}<0.4 \text { to } 0.5
$$

d. Noninterfering currents strong enough to transport material resulted in tombolo formation for an intermediate ratio value:

$$
\frac{L_{s}}{X}=0.67 \text { to } 1.0
$$

17. Gourlay makes the following observations about beach response to prototype breakwaters based on performance of structures in California, Japan, and Israe1:

a. Tombolo formation can only occur if the structure is inside the surf zone and

$$
\frac{L_{s}}{X}>0.67
$$

b. For cases in which the structure is outside the surf zone, the seaward extent of the beach response (salient) is determined by the breaking point location.

\section{$\underline{\text { Rosen and Vadja (1982) }}$}

18. Rosen and Vadja (1982) graphically present relationships to predict the equilibrium salient and tombolo size based on structure and site parameters. Relationships to predict salient formation are based on a physical model study of beach response $(0.64-\mathrm{mm}$ sand) to an impermeable breakwater under normal wave incidence conducted by Rosen and Vadja, including laboratory data measured by Shinohara and Tsubaki (1967) and prototype data from Israeli, 
US, and Japanese structures. Given a desired salient length in the onoffshore direction (measured from original shoreline) $X_{\mathrm{s}}$, and a dimensionless breaker distance $X_{\mathrm{b}} / X$, where $X_{\mathrm{b}}$ is the distance from the original shoreline to the mean breaker line, the recommended ratio $L_{\mathrm{s}} / X$ can be graphically determined (Figure 2).

19. Several relationships are also presented for determining tombolo size in the equilibrium state, based on the field data of Inman and Frautschy (1966), Toyoshima (1976), and Nir (1976) (Figure 3). Given project variables $L_{\mathrm{s}}, X$, and beach slope $I$, the following parameters can be estimated: the volume of sand trapped in the tombolo $Q$, length of tombolo in alongshore direction (measured at structure) $L_{\mathrm{T}}$, and area of tombolo $A_{\mathrm{T}}$.

Shore Protection Manual (SPM) (1984)

20. Based on the pattern of diffracting wave crests in the lee of a breakwater, the US Army Corps of Engineers' Shore Protection Manual (SPM 1984) recommends that the structure length be less than the distance offshore to inhibit tombolo formation:

$$
\frac{L_{s}}{X}<1.0 \quad \text { tombolo formation prevented }
$$

This structure-distance ratio usually allows diffracting wave crests to intersect in the shadow zone of the structure prior to undistorted wave crests reaching the adjacent beach. For normal wave approach, the approximate location of the salient apex is the intersection of the diffracting wave crests as they reach the shoreline.

21. The SPM recommends the following limit to ensure tombolo formation:

$$
\frac{L_{s}}{X}>2.0 \text { tombolo formation certain }
$$

\section{Dally and Pope (1986)}

22. Dally and Pope (1986) recommend limits of the structure-distance ratio based on the type of shoreline advance desired (either nonuniform, where salients or tombolos occur, or uniform, in which an equal advance of the beach occurs), and the length of the beach to be protected. For nonuniform 


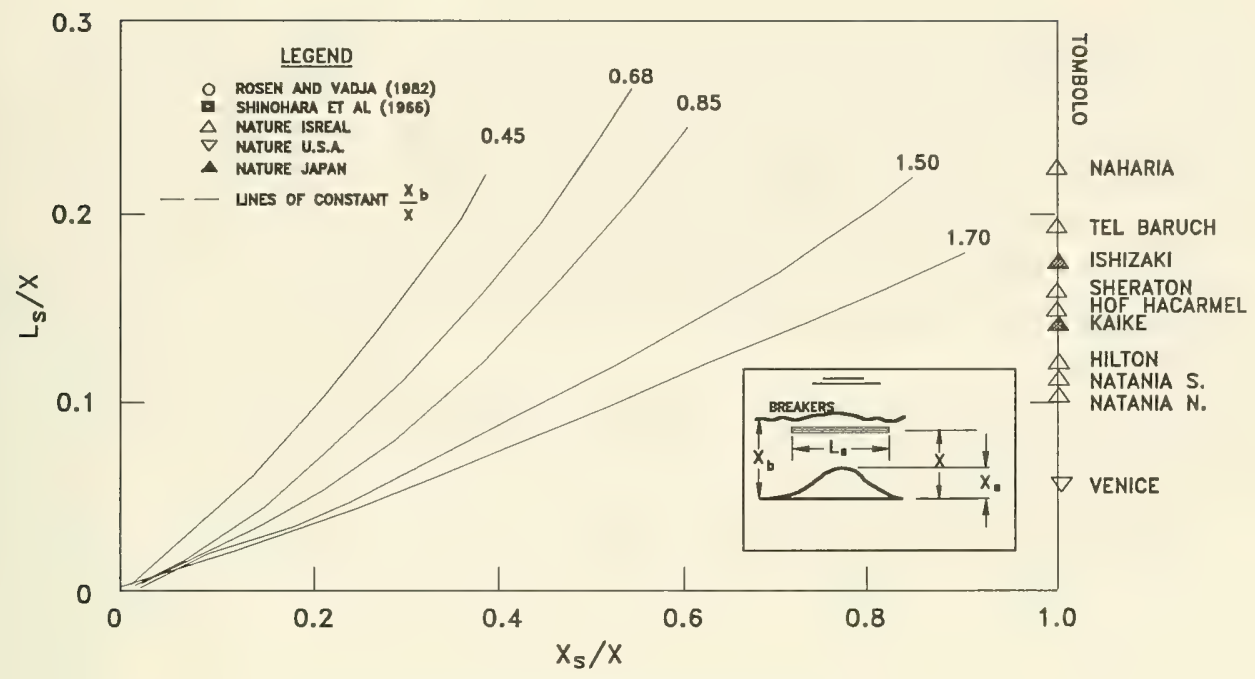

Figure 2. Equilibrium salient formation (after Rosen and Vadja 1982)

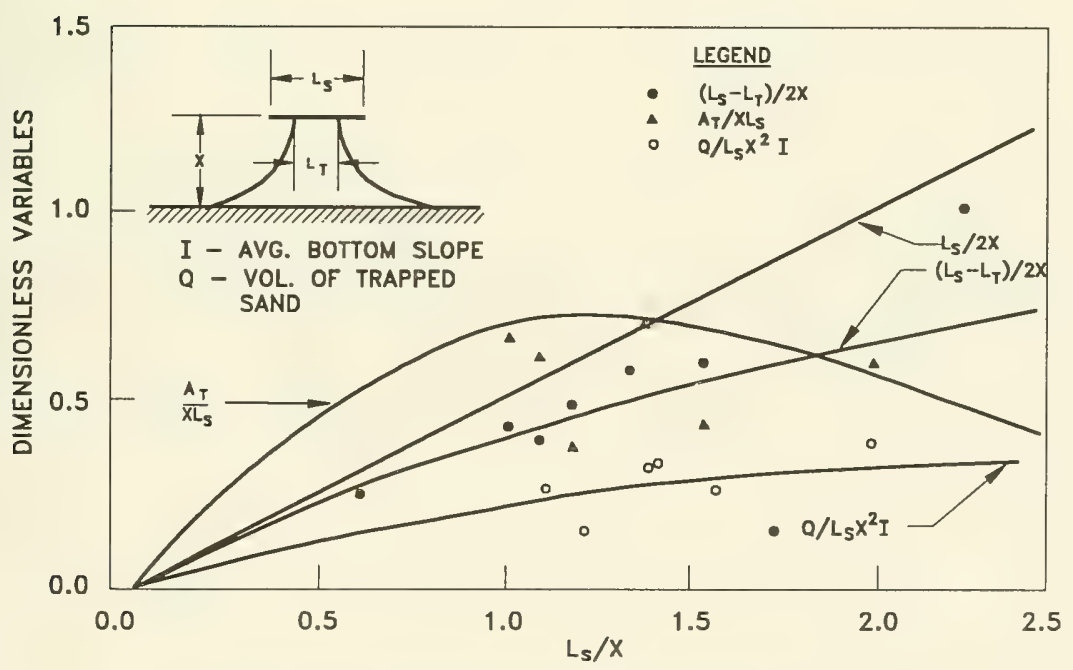

Figure 3. Equilibrium tombolo formation (after Rosen and Vadja 1982) 
protection over relatively short project distances, a single impermeable detached breakwater is recommended with a structure length as long as the project beach. If the depth of construction implied by the calculated distance offshore (see relationships below) is too great, Dally and Pope (1986) recommend moving the structure shoreward to a feasible depth and increasing structure transmissibility. Longer project shorelines should be protected with a relatively impermeable segmented system for nonuniform shoreline advance.

a. The following structure-distance ratios (and gap distance, for segmented systems) are recommended for tombolo formation:

$$
\begin{gathered}
\frac{L_{s}}{X}=1.5 \text { to } 2 \text { single breakwater } \\
\frac{L_{s}}{X}=1.5, L \leq L_{g} \leq L_{s} \text { segmented breakwater }
\end{gathered}
$$

where $L$ is the wavelength at the structure and $L_{g}$ is the gap distance between adjacent breakwater segments.

b. The structure-distance ratio is reduced for salient formation:

$$
\frac{L_{s}}{X}=0.5 \text { to } 0.67 \text { single and segmented breakwaters }
$$

c. For uniform protection of a site, a structure located well outside the normal surf zone is recommended. Either a highly permeable, partially submerged structure (60-percent transmissibility is recommended) or an impermeable, frequently segmented structure will allow the required degree of wave energy to enter the shadow zone of the structure for uniform shoreline advance. The recommended structure-distance ratio for a segmented system is as follows:

$$
\frac{L_{s}}{X}<0.125 \text { segmented breakwaters }
$$

\section{Toyoshima $(1972,1974)$}

23. Toyoshima recommends breakwater design guidance based on experience gained through observation of prototype performance of 86 single and segmented 
breakwater systems (217 segments total) along the Japanese coast. The relationships are categorized based on the proposed depth at the structure: the shoreline system, where the structure is placed at or near the waterline; the shallow-water system, with a structure depth less than or equal to $1 \mathrm{~m}$; and the median-depth system, for structures in a depth of 2 to $4 \mathrm{~m}$. Relationships are not given for a deepwater system, which is described as being located at the outside of the surf zone for the purpose of dissipating wave energy rather than sediment deposition.

a. The shoreline system is recommended for sites with either a steep beach slope, where only small-scale sand deposition is required, to protect an existing structure from wave attack (i.e., seawa11), or to maintain the existing beach width. The "group island type" (segmented) breakwater is recommended, constructed of two-layer pile armor blocks. A problem noted with shoreline system structures is large-scale scour on the seaward face of the structure, especially if the structure is exposed to significant wave attack.

$$
\begin{gathered}
\frac{L_{s}}{L}=2 \text { to } 3 \quad \begin{array}{l}
\text { segmented breakwater } \\
\text { (recommended } \left.L_{s}=40 \text { to } 60 \mathrm{~m}\right)
\end{array} \\
L_{g}=L \quad\left(\text { recommended } L_{g}=20 \mathrm{~m}\right)
\end{gathered}
$$

b. The shallow-water depth system (constructed in depths less than $1 \mathrm{~m}$ ) is recommended for gently sloping beaches or at sites where the structures are expected to be constructed from the beach using a track and crane method. A "group island type" (segmented) system is recommended, constructed of armor blocks with a crest elevation approximately one-half the wave height above high-water level ( 1 to $1.5 \mathrm{~m}$ above high-water level).

$$
\begin{gathered}
\frac{L_{s}}{L}=3 \text { to } 5 \text { segmented breakwater } \\
\text { (recommended } \left.L_{s}=60 \text { to } 100 \mathrm{~m}\right) \\
L_{g}=L \quad\left(\text { recommended } L_{g}=20 \mathrm{~m}\right)
\end{gathered}
$$

If an island breakwater is used (single breakwater), Toyoshima recommends that the following segment length ratio: 


$$
\frac{L_{s}}{L} \leq 10 \text { single breakwater }
$$

c. The median-depth system (structures constructed in the surf zone, 2 - to 4-m depth) was the most common type of system observed in Toyoshima's survey of Japanese breakwaters. For reduction of wave energy, a continuous structure (long single breakwater) is recommended, while either an island (single) or group island type (segmented) breakwater is recommended for the primary purpose of sediment deposition. Construction is through the use of a floating plant; a rubble-mound or composite type rather than armor block construction is recommended to reduce costs. As was recommended for the shallow-water depth system, the structure crown height should be one-half wave height above the high-water level ( 1 to $1.5 \mathrm{~m}$ above high water). For single breakwaters, the following structure ratio is recommended:

$$
\frac{L_{S}}{L}=3 \text { to } 10 \quad \text { (recommended } L_{s}=100 \text { to } 300 \mathrm{~m} \text { ) }
$$

For a segmented system, the structure lengths are decreased:

$$
\begin{gathered}
\frac{L_{s}}{L}=2 \text { to } 6 \quad \text { (recommended } L_{s}=60 \text { to } 200 \mathrm{~m} \text { ) } \\
L_{g}=L \quad\left(\text { recommended } L_{g}=20 \text { to } 50 \mathrm{~m}\right)
\end{gathered}
$$

For both single and segmented systems, the following structuredistance ratio is recommended as a standard:

$$
\frac{L_{s}}{X}=1 \text { to } 3.3
$$

For a continuous breakwater,

$$
\frac{X}{L}=1 \text { to } 3 \text { (recommended } X=30 \text { to } 100 \mathrm{~m} \text { ) }
$$

24. Toyoshima used the described guidance to design more than 20 systems along the Kaike coast, Japan, and concludes that the structures were successful in accomplishing their intended purpose. He recommends, however, 
that a countermeasure for beach erosion be considered for the beach opposite the breakwater gaps, as this area is often eroded after breakwater installation. In later discussions of the Kaike coast project (Toyoshima 1976, 1982), performance of the breakwaters is still considered successful, although subsidence of the structures is reported to be a significant contributor in reducing their efficiency.

Wa1ker, Clark, and Pope (1980)

25. Walker, Clark, and Pope discuss the method used to design the Lakeview Park, Lorain, $\mathrm{OH}$, segmented detached breakwater project for salient formation. This technique, hereafter referred to as the Diffraction Energy Method, involves construction of diffraction coefficient $K_{\mathrm{D}}$ isolines for representative waves from predominant directions. Detached breakwaters along the California coast, particularly the Venice breakwater, were observed to have shorelines approximated by the intersection of $K_{\mathrm{D}}$ isolines equal to 0.3. Walker, Clark, and Pope theorize that storm waves, usually an order of a magnitude greater than the average wave conditions, are able to transport material at least as far shoreward as the average wave $K_{\mathrm{D}}$ equal to 0.3 isolines. Thus, these isolines are a good indicator of the likely shoreline position. The Lakeview Park project was designed such that the $K_{\mathrm{D}}=0.3$ isolines intersected lakeward of the project beach fill but shoreward of the three breakwater segments, ensuring that tombolo formation would not occur. Actual shoreline response to the structures was slightly different than had been expected: the west end of the project beach was continually eroded, despite beach-fill replenishment. The most likely reason for the discrepancy between design and actual shoreline response, however, may not be the design method itself but the wave climate chosen for design (USAED, Buffalo 1975; Pope and Dean 1986), as waves from the northwest were inappropriately weighted.

Pope and Dean (1986)

26. Pope and Dean (1986) present bounds of observed beach response based on prototype performance of seven US detached breakwater projects. The occurrence of tombolo, salient, or nonsinuous beach response is given as a function of two dimensionless parameters: the segment length-to-gap ratio and an effective distance offshore-to-depth at structure ratio, where $d$ is the depth at the structure (Figure 4). High- and low-water conditions are 


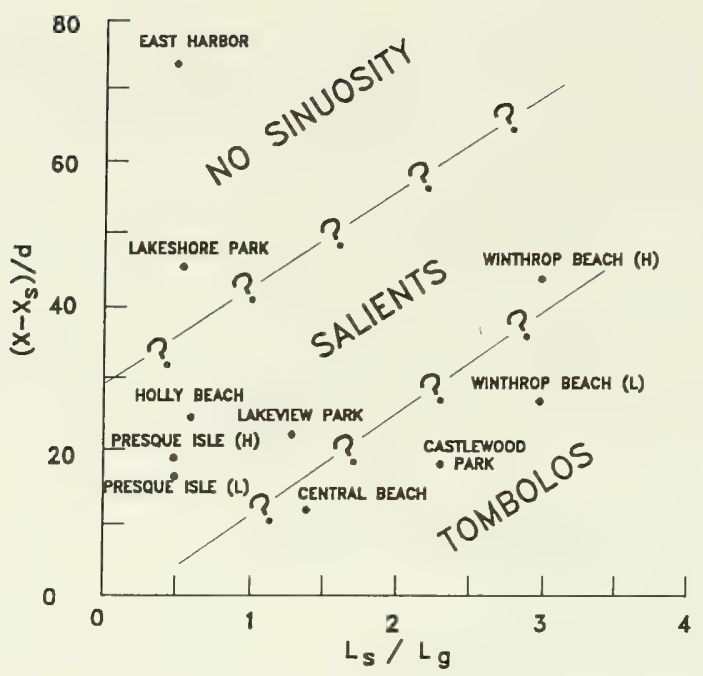

Figure 4. Morphological response as a function of structural parameters (after Pope and Dean 1986)

differentiated in Figure 4 for those projects with a large water level range (Presque Isle and Winthrop Beach) by the symbols (H) and (L), respectively. Ahrens and Cox (in press)

27. Ahrens and Cox (in press) used the beach response index classification scheme presented by Pope and Dean (1986) to develop a relationship for expected morphological response as a function of the segment-to-gap ratio:

$$
I_{s}=e^{\left(1.72-0.41 \frac{L_{s}}{x}\right)}
$$

where $I_{\mathrm{s}}$ is the beach response index, coded as follows:

$$
\begin{array}{ll}
I_{\mathrm{s}}=1 & \text { permanent tombolo formation } \\
I_{\mathrm{s}}=2 & \text { periodic tombolos } \\
I_{\mathrm{s}}=3 & \text { well-developed salients } \\
I_{\mathrm{s}}=4 & \text { subdued salient } \\
I_{\mathrm{s}}=5 & \text { no sinuosity }
\end{array}
$$


Berenguer and Enriquez (1988)

28. Berenguer and Enriquez (1988) developed design guidance for pocket beaches, projects where sediment transport is laterally and frontally limited, based on performance of 24 projects along the Spanish Mediterranean coast. The authors noted that the longest alongshore distance between adjacent salient/tombolos, $L_{\mathrm{a}}$, was approximately twice the on-offshore distance between the gap and shoreline $\left(X+X_{g}\right)$, where $X_{g}$ is the erosion/accretion opposite the gap, measured from the original shoreline:

$$
L_{a}=2\left(X+X_{g}\right)
$$

Relating this gap erosion distance to the length of gap, the authors found that

$$
\left(X+X_{g}\right)=25+0.85 L_{g}
$$

and

$$
X L_{b}=2.5\left(X+X_{g}\right)^{2}
$$

where $L_{\mathrm{b}}$ is the alongshore center-to-center distance between adjacent segments. Assuming a semicircular beach response in the area defined by $L_{\mathrm{b}}$ and $X$, the maximum surface area (i.e., beach fill) that could be stable $S_{p}$ can be calculated:

$$
S_{p}=0.37 \times L_{b}
$$

For values of $L_{\mathrm{g}} d_{\mathrm{g}}$ between 150 and $500 \mathrm{sq} \mathrm{m}$, where $d_{\mathrm{g}}$ is the depth at gap, Berenguer and Enriquez developed a relationship to predict the gap erosion ( $X$ $+X_{g}$ ) given the average sediment size at the site $D_{50}$ (Figure 5). Ahrens $^{*}$

29. Ahrens extended the results of Berenguer and Enriquez (1988) by

* Personal Communication, 1989, John Ahrens, Research Physical Scientist, US Army Engineer Waterways Experiment Station, Vicksburg, MS. 


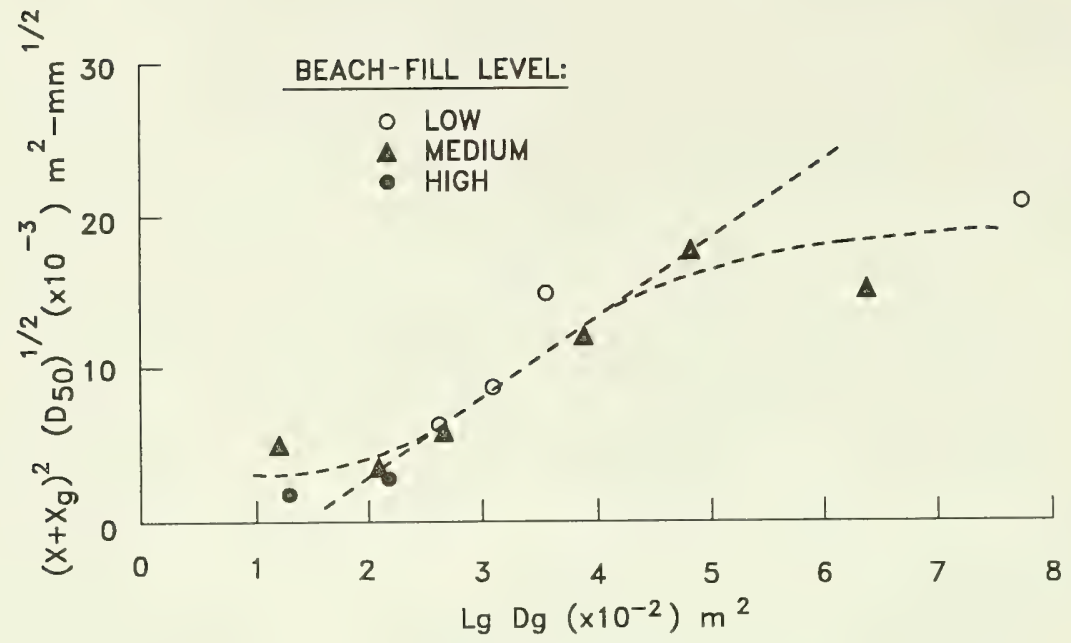

Figure 5. Relationship to predict gap erosion for pocket beaches (after Berenguer and Enriquez 1988)

performing a regression analysis of the Mediterranean pocket beach data and making some simplifying assumptions about wave height at the gap, $H_{g}$. The wave height was assumed equal to 0.78 times the depth at the gap, $d_{g}$, with a maximum value of $3.0 \mathrm{~m}$. The variables $H_{g}, d_{g}$, and $L_{8}$ should be in meters, and $D_{50}$ in millimeters (the relationship is not dimensionless). The gap erosion $\left(X+X_{\mathrm{g}}\right)$ is predicted well, with a squared correlation coefficient of 0.78 :

$$
\left(X+X_{g}\right)=6.67 \frac{d_{g}^{0.8} L_{g}^{0.4} H_{g}^{0.2}}{D_{50}}
$$




\section{Seiji, Uda, and Tanaka (1987)}

30. Based on a survey of over 1,500 breakwaters in Japan, Seiji, Uda, and Tanaka (1987) predict the following gap erosion relationships, where gap erosion is defined as retreat of shoreline to the lee of the gap from the initial (preproject) shoreline position:

$$
\begin{gathered}
\frac{L_{g}}{X}<0.8 \text { no erosion opposite gap } \\
0.8 \leq \frac{L_{g}}{X} \leq 1.3 \text { possible erosion opposite gap } \\
\frac{L_{g}}{X} \geq 1.3 \text { certain erosion opposite gap }
\end{gathered}
$$

\section{Noble (1978)}

31. Noble (1978) evaluated the effects of detached structures along the California coast and those discussed in the literature and concluded that "detached breakwaters produce only minimal impact when the offshore distance of the structure is greater than six times the breakwater length." That is,

$$
\frac{L_{s}}{X} \leq \frac{1}{6} \text { minimal impact }
$$

\section{Noda (1984)}

32. Noda (1984) conducted a series of movable-bed (0.2-mm sand)

laboratory experiments evaluating physical parameters controlling the development of tombolos and salients, especially due to on-offshore transport. Noda used both storm and swell-type waves and concluded that maximum deposition occurs when

$$
0.5 \leq \frac{X}{X_{b}} \leq 1.0
$$


33. Well-developed tombolos were observed to form when

$$
\frac{X}{X_{b}}=0.56
$$

and a bimodal tombolo developed for

$$
\frac{X}{X_{b}}=0.39
$$

The total amount of sand deposition per unit width of gap was observed to be about three times the quantity of material transported shoreward through a permeable breakwater, when dimensions of the structures are "chosen appropriately." When structures were placed seaward of the breaker line, no sand was observed to move seaward through the structures; when structures were placed near the shoreline, Noda observed that sand may move offshore. Hallermeier (1983)

34. In a review of field and laboratory sediment depositional patterns in the vicinity of coastal structures, Hallermeier (1983) developed a relationship for the depth limit of sediment transport. Hallermeier recommends the following depth as a guide when positioning detached breakwaters when tombolo formation is deemed undesirable:

$$
d_{s a}=\frac{2.9 H_{\theta}}{\sqrt{(S-1)}}-\frac{110 H_{\theta}^{2}}{(S-1) g T_{\theta}^{2}} \text { depth for salient formation }
$$

where

$d_{\text {sa }}=$ annual seaward limit of the littoral zone

$H_{\mathrm{e}}=$ deepwater wave height exceeded $12 \mathrm{hr}$ per year

$S=$ ratio of sediment to fluid density

$\mathrm{g}=$ acceleration of gravity

$T_{\theta}=$ wave period corresponding to $H_{\mathrm{e}}$

35. For headland structures (tombolo development), structures should be sited near

$$
d=\frac{d_{s a}}{3} \text { headland structures }
$$




\section{Suh and Dalrymple (1987)}

36. Based on unscaled monochromatic movable-bed laboratory tests, Suh and Dalrymple (1987) give relationships for salient length, $X_{\mathrm{s}}$, given structure length $L_{s}$ and location in surf zone for single offshore breakwaters:

$$
\begin{array}{ccc}
X_{s}=0.156 L_{s} & \frac{X_{b}}{X}<0.5 & R=0.98 \\
X_{S}=0.317 L_{s} & 0.5<\frac{X_{b}}{X}<1.0 & R=0.85 \\
X_{s}=0.377 L_{s} & \frac{X_{b}}{X} \geq 1.0 & R=0.75
\end{array}
$$

where $R$ is the correlation coefficient.

37. Combining the laboratory results with available prototype data, the following relationship for salient length is obtained:

$$
X_{s}=X(14.8) \frac{L_{g} X}{L_{s}^{2}} e^{\left(-2.83 \sqrt{\frac{L_{g} X}{L_{s}^{2}}}\right)}
$$

Tombolos usually formed for single prototype breakwaters when

$$
\frac{L_{s}}{X} \geq 1.0
$$

For multiple offshore breakwaters, tombolos formed when

$$
\frac{L_{g} X}{L_{s}^{2}} \sim 0.5
$$

Harris and Herbich (1986)

38. Harris and Herbich (1986) conducted a series of movable bed $\left(D_{50}=0.63 \mathrm{~mm}\right)$ monochromatic physical model tests to evaluate the effect of 
detached breakwater gap spacing on sand entrapment. Relationships for the average quantity of sand deposited to the lee of each breakwater, $Q_{b}$, both to the lee of the breakwater and in the gap area, $\left(Q_{b}+Q_{g}\right)$, and in the gap area alone are presented in Figures 6 through 8 . Combining model results with prototype data, Harris and Herbich relate the dimensionless accreted volume to structure parameters as follows:

$$
\frac{Q_{b}}{X L_{s} d}=e^{\left[0.31-1.92\left(\frac{X}{L_{s}}\right)\right]}
$$

The relationship is based on data with values of $X / L_{\mathrm{s}}$ ranging from 0.5 to 2.5 .

\section{Sonu and Warwar (1987)}

39. Sonu and Warwar (1987) empirically relate the growth of the Santa Monica, CA, tombolo through time as follows:

$$
Q=Q_{0}\left(1-e^{-A t}\right)
$$

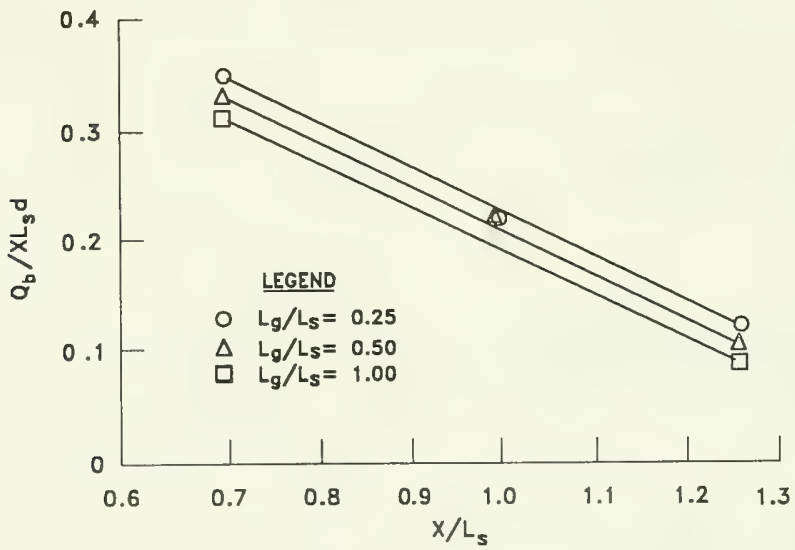

Figure 6. Effect of gap spacing on sand deposition to lee of breakwater (after Harris and Herbich 1986) 


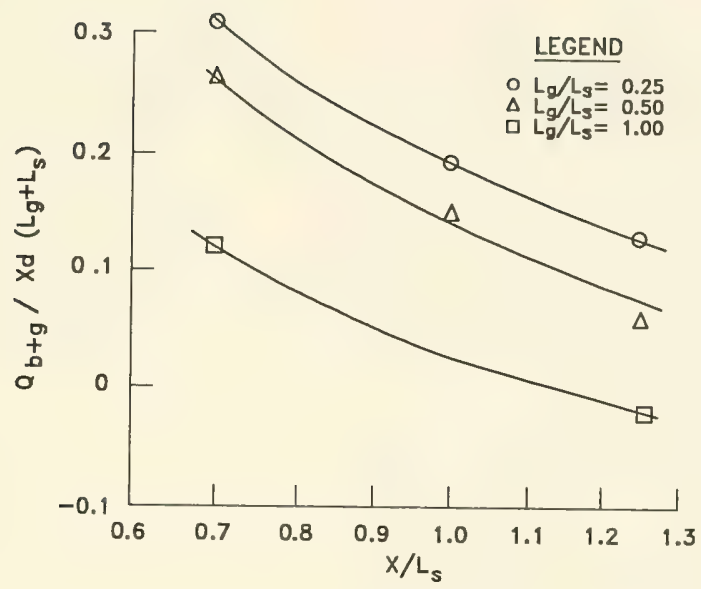

Figure 7. Effect of gap spacing on sand deposition for each breakwater gap pair (after Harris and Herbich 1986)

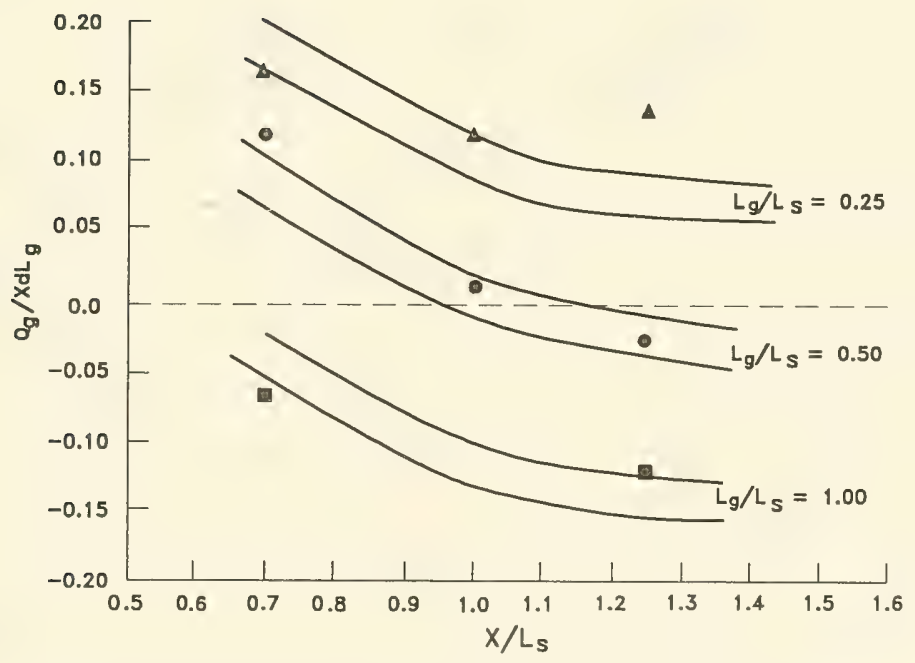

Figure 8. Effect of gap spacing on sand deposition for gap region (after Harris and Herbich 1986) 
where $Q_{0}$ is the volume at final equilibrium state, equal to $2,100,000 \mathrm{cu}$ $\mathrm{yd}^{* \hbar}$ for the Santa Monica breakwater and $A$ is an empirical coefficient, determined as 0.104 year $^{-1}$. The authors conclude that, without dredging events, the Santa Monica breakwater would have reached 90-percent growth in 22 years.

\section{Silvester and Ho (1972)}

40. For beaches that have equilibrated with headland structures, Silvester and Ho (1972) present a relationship to predict the maximum gap indention $\left(X+X_{g}\right)$ given a gap distance $L_{g}$ and predominant wave direction $\beta$ (degrees) (Figure 9).

\section{Japanese Ministry of Construction (1986)}

41. The empirical method of breakwater design described by the JMC in their "Handbook of Offshore Breakwater Design" (1986) has several advantages over the empirical relationships presented previously. The JMC method is a step-by-step iterative procedure, allowing the designer to follow specific

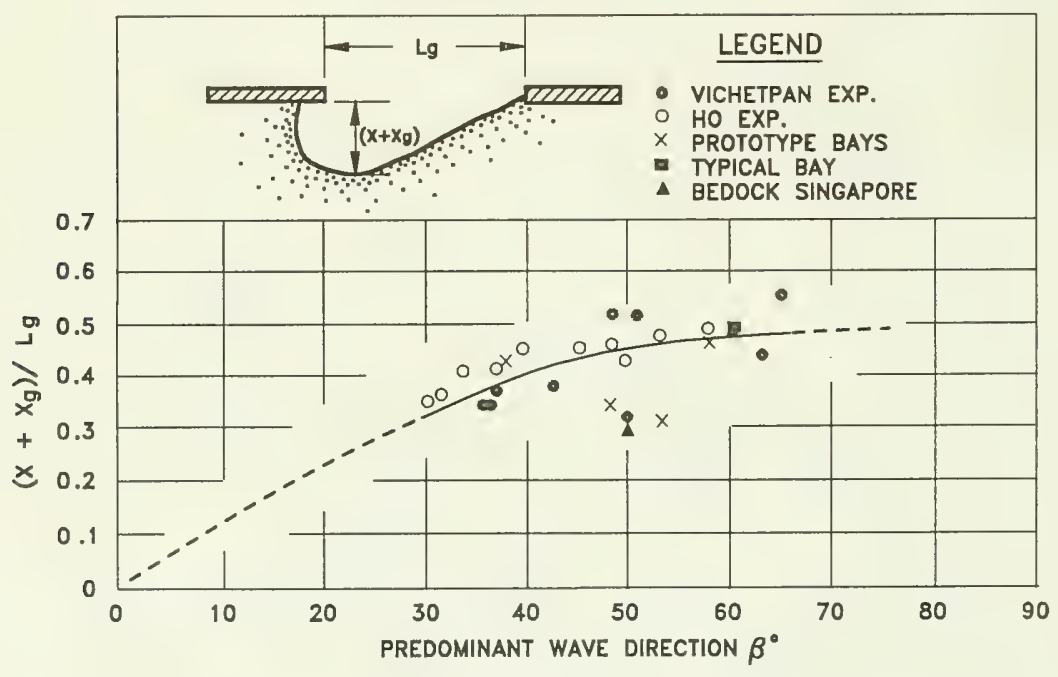

Figure 9. Relationship to predict gap erosion for headland structures (after Silvester and Ho 1972)

** To convert cubic yards into cubic metres, multiply by 0.7645549 . 
guidelines towards the final design. Rosati and Truitt (1990) discuss the JMC method of breakwater design and present several example problems.

42. However, the JMC method has its disadvantages for use in design of US detached breakwater systems. Approximately 60 percent of the projects on which the method is based resulted in tombolo formation; therefore, it is more appropriate for headland or pocket beach-type systems, rather than detached breakwater or reef systems. Unlike US breakwater projects, beach fill is not placed as a part of the JMC's projects; therefore, there is no provision for beach fill in the iterative method. All structures considered in the JMC study were permeable; however, the effect of increased or decreased structure transmissibility is not included in the JMC method. For construction of a highly transmissible structure such as a reef breakwater or perched beach, use of the JMC method for design is most likely inappropriate. The wave height required for input is the average of the highest five nonstorm waves that occur in a typical year and corresponding wave period, often difficult parameters to extract from typically available hindcast wave data sets. The effects of a variable water level on design are not explicitly accounted for in the procedure. 


\section{PART III: ASSESSMENT OF DESIGN TECHNIQUES}

\section{Introduction}

43. To evaluate the empirical design methods presented in Part II, data from five US breakwater projects have been compiled (Table 1) and prototype response compared with that predicted by the relationships. Variables presented in Table 1 are defined in Appendix A. These projects encompass a range of structural and site parameters and observed beach response, from salient formation (Lakeview Park and Redington Shores), to no beach response (Lakeshore Park), and periodic tombolo formation (Colonial Beach, Central and Castlewood Park Beaches).

\section{Evaluations}

\section{Morphological response}

44. Two types of predictive relationships were discussed that relate to morphological response: those that predict a nondepositional, salient, or tombolo response as a function of structural parameters; and a relationship predicting seaward salient excursion. By far, the majority of the relationships presented fall into the first category; an evaluation of these relationships by author is presented in Figure 10. Dashed horizontal lines in the figure separate the boundaries between the indicated morphological responses; solid lines indicate the range recommended by the cited author.

45. A trend is apparent in the prototype data for deposition to increase as the structure length to distance offshore ratio increases. However, the ability of the relationships to accurately predict observed response is at best fair. If other types of design tools are available, it is recommended that these simple empirical relationships be used only as a general guide when designing a project.

46. Suh and Dalrymple's (1987) relationship for salient length (Equation 42) was applied to all segmented projects (Equation 42 does not apply to single structures since gap distance $L_{\mathrm{g}}$ is not defined). The relationship tends to overpredict the seaward excursion of the spit for the majority of prototype data evaluated (Figure 11), but appears to predict very well for the 


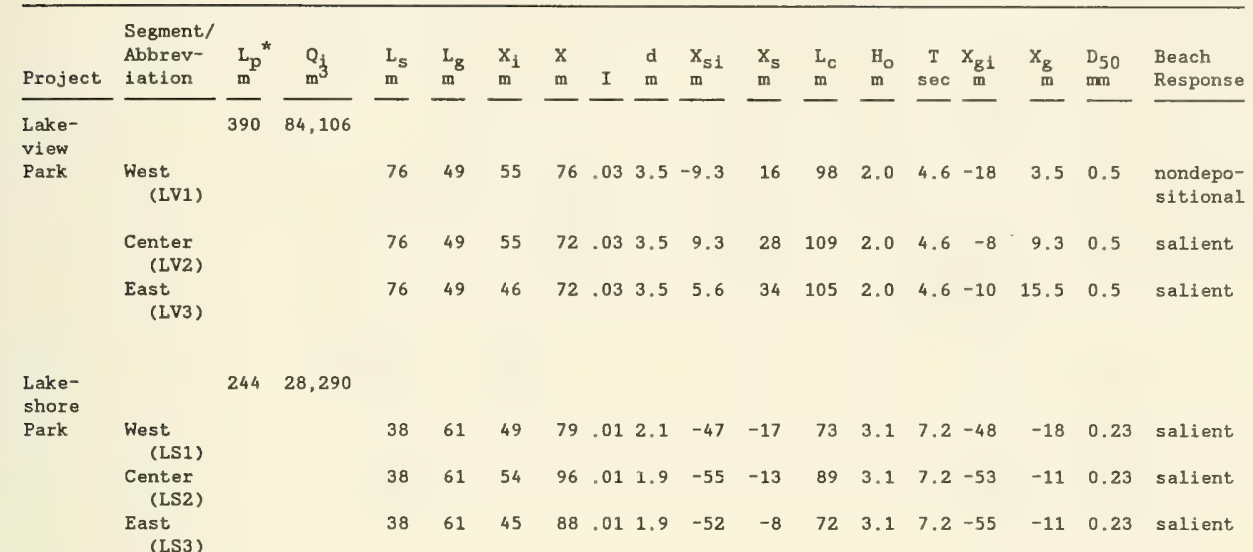

Reding-

ton

Shores

$312 \quad 23,000$

$\begin{array}{lllllllllllllll}112 & -- & 85 & 95 & .05 & 2.4 & 22 & 32 & 127 & 1.0 & 5.2 & -16 & -6 & 0.14 & \text { salient }\end{array}$

$460 \quad 40,370$

Colonial

Beach,

Central Upriver

(CB1)

Center-

upriver

(CB2)

Center-

down-

river

(CB3)

Down-

river

(CB4)

Colonial

Beach,

Castle- Upriver

wood

(CP1)

Park

Center

(CP2)

Down-

river

(СP3)

$325 \quad 11,470$

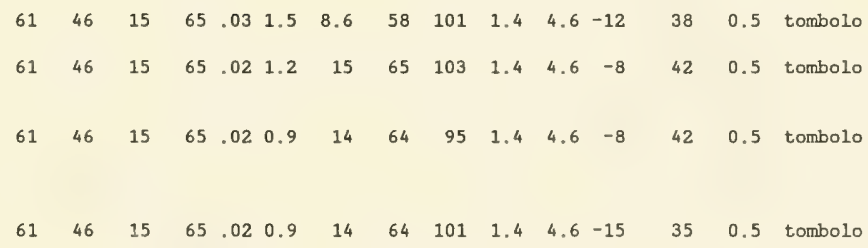

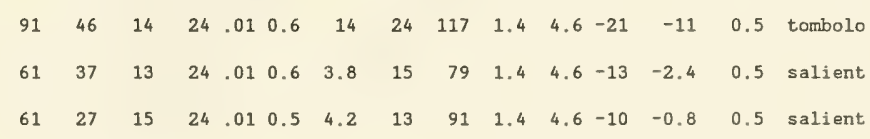

\footnotetext{
$L_{p}=$ Alongshore project length; $Q_{i}=$ Quantity of beach-fill placed in project area; $X_{i}=$ Breakwater segment distance from initial beach-fill shoreline; $X_{\text {Si }}=$ salient/tombolo length in on-offshore direction measured from initial beach-fill shoreline; $\mathrm{X}_{\mathrm{gi}}=$ Erosion/accretion opposite gap, measured from initial beach-fill shoreline.
} 


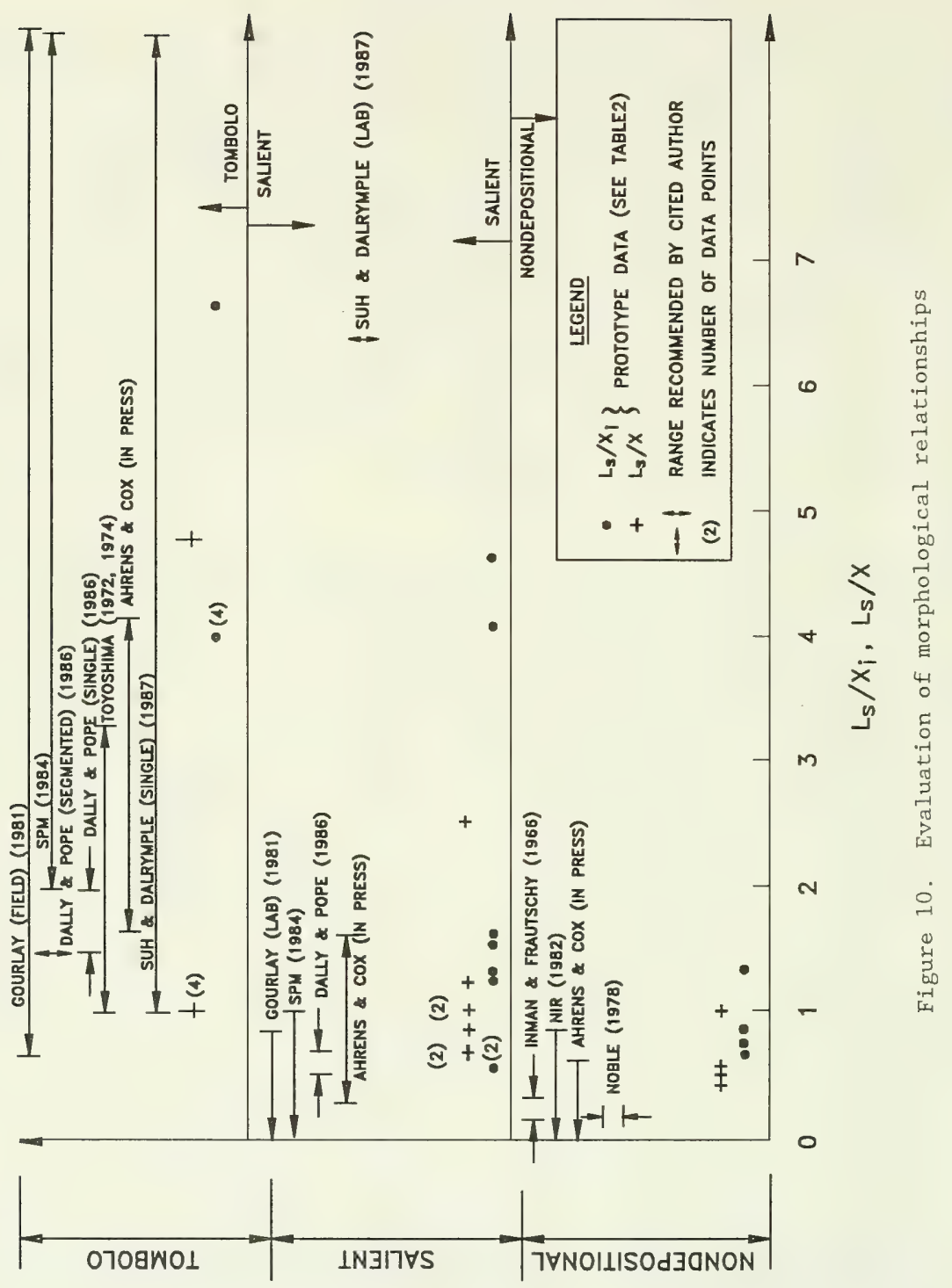




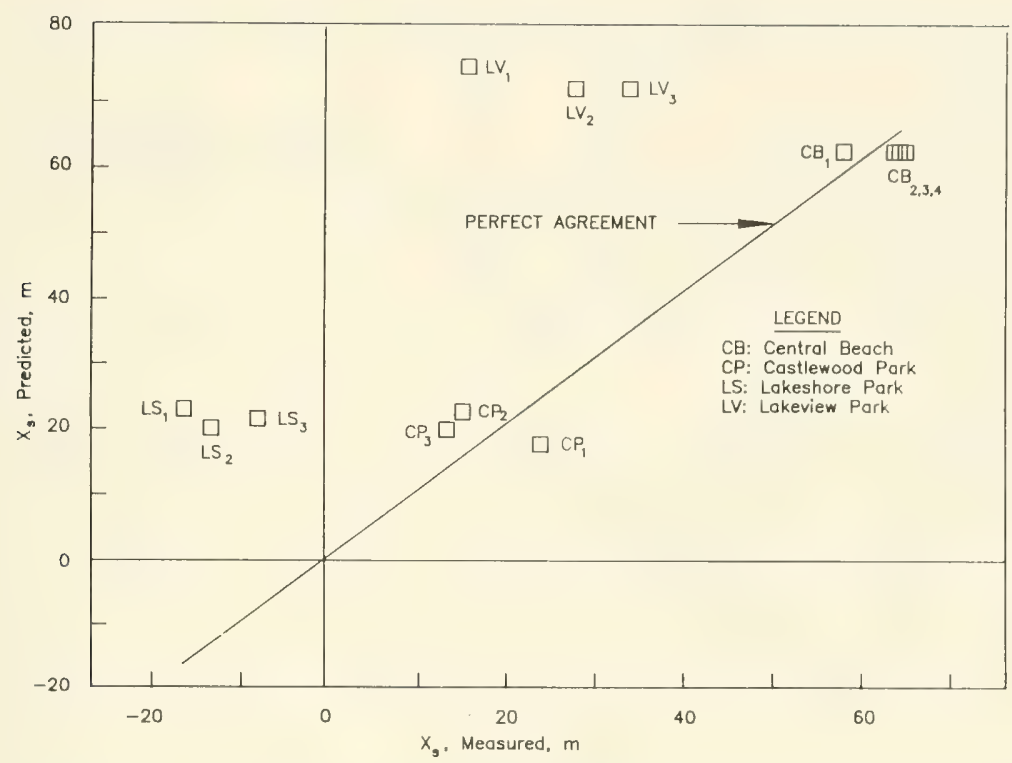

Figure 11. Evaluation of Suh and Dalrymple's (1986) relationship for salient length

pocket-beach type structures with periodic tombolo formation (Central Beach and Castlewood Park Beach). The correlation coefficient $R$ is equal to 0.67.

47. Because data defining the equilibrium volume and spit thickness to the lee of each breakwater segment were not readily available for US projects, a direct comparison between Harris and Herbich's (1986) volumetric and Nir's (1982) thickness relationships (Equations 45 and 3, respectively) could not be performed. However, the measured spit area was directly compared with a predicted area value using Harris and Herbich's volumetric relationship divided by Nir's spit thickness parameter. It should be recognized that this combined evaluation is not a true assessment of either method; however, it does give an indication of whether the combined relationships are accurate in predicting spit area. The measured spit area is calculated by assuming a triangular shape of the salient/tombolo. Much scatter is apparent in the comparison (Figure 12), with a correlation coefficient equal to 0.18.

48. Seiji, Uda, and Tanaka's (1987) ranges to predict gap erosion (Equations 30 through 32) were evaluated (Figure 13). The lower boundary for 


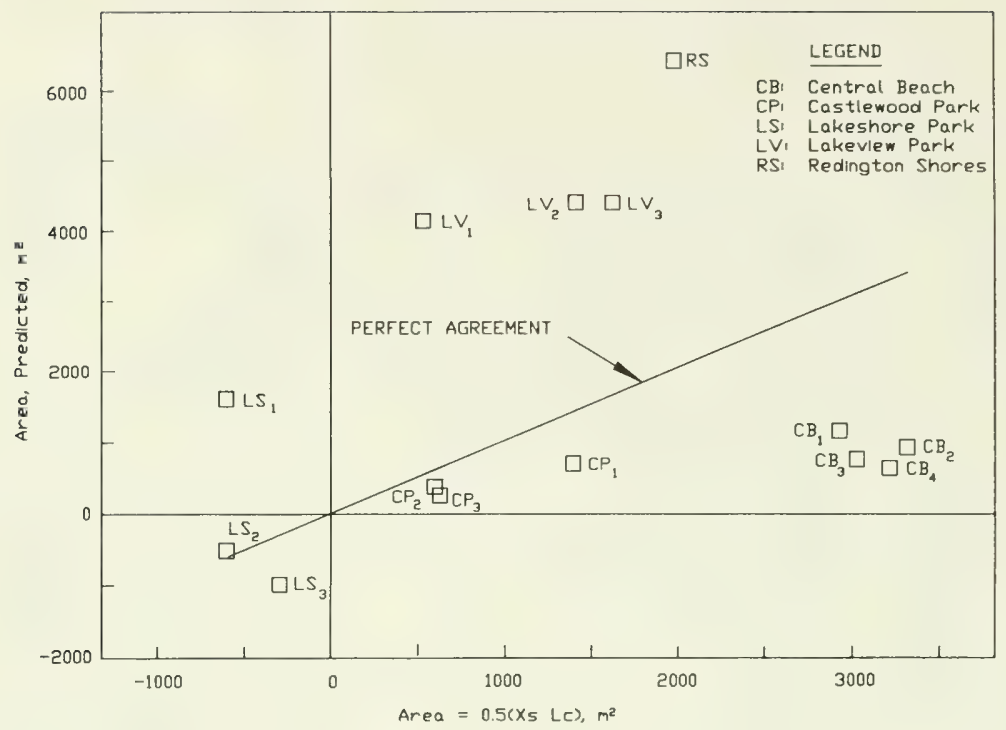

Figure 12. Combined evaluation of Harris and Herbich's (1986) and Nir's (1982) relationships

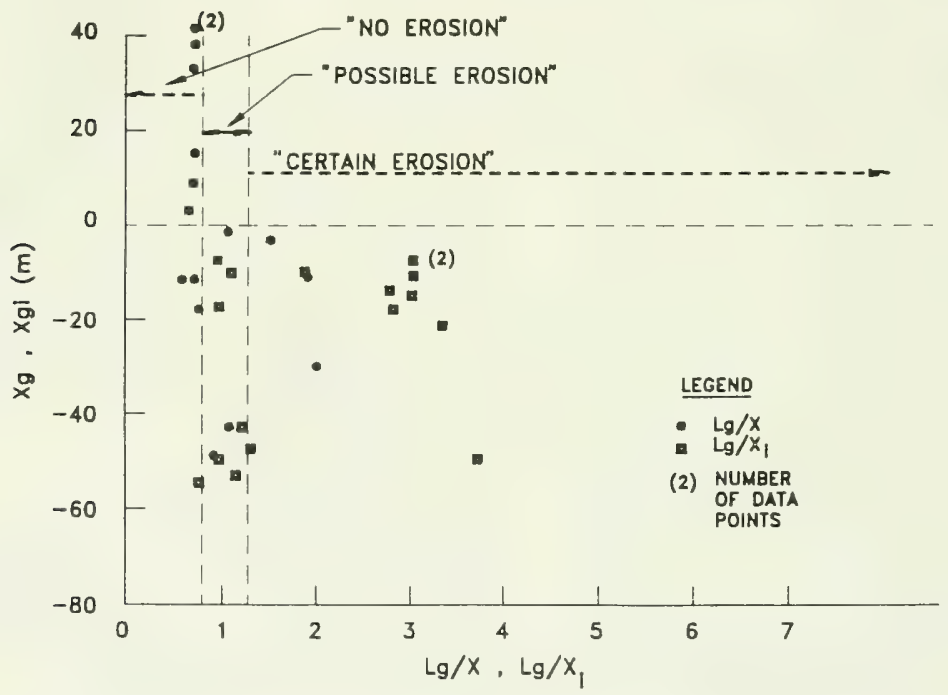

Figure 13. Evaluation of Seiji, Uda, and Tanaka's (1987) limits for gap erosion 
"no erosion" $\left(L_{g} / X \leq 0.8\right)$ was a reasonably good predictor of either accretion or very little erosion. Gap erosion occurred for ratios of $L_{\mathrm{g}} / X$ greater than 0.8 .

49. Berenguer and Enriquez' (1988) and Ahrens' formulae to predict gap erosion (Equations 26 and 29, respectively) for pocket beaches were evaluated using data from the two sites at Colonial Beach (headland structures). Both relationships are inversely proportional to the data (Berenguer and Enriquez: $R=-0.99$, Ahrens: $R=-0.24$ ) (Figure 14).

\section{Structure depth}

50. Hallermeier's (1983) relationship for recommended structure depth was evaluated using the recommended depth for salient formation (Equation 37) for all sites except Colonial Beach, where the recommended depth for tombolo formation (Equation 38) was used (Figure 15). An excellent correlation between depth at the structure and Hallermeier's recommended depth exists for all but the Lakeshore Park data, resulting in a correlation coefficient $R=0.55$.

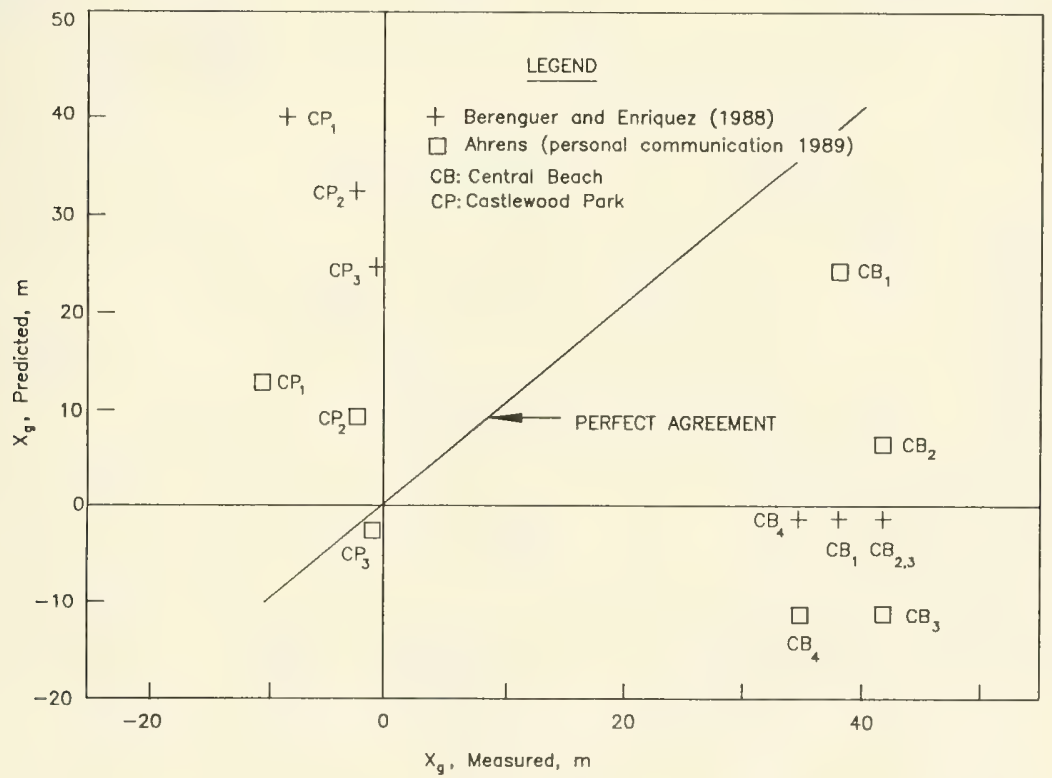

Figure 14. Evaluation of Berenguer and Enriquez' (1988) and Ahrens' relationships for pocket beach gap erosion 
JMC method

51. As mentioned in Part II, the JMC method of breakwater design has limitations for use with typical us projects: beach fill is not included as a part of the design method; guidance is based on data from sites at which tombolo formation occurred for the majority of cases; wave conditions required for design are the wave height and period corresponding to the "average of the largest five nonstorm waves occurring in a typical year"; and the effects of structural transmissibility and water-level variations are not parameters in the method. A comparison of the JMC and typical US design using data from the Lakeview Park, Lorain, $\mathrm{OH}$, detached breakwater project was presented by Rosati and Truitt (1990). Figure 16 presents project parameters resulting from the JMC method, which can be compared with the as-constructed parameters resulting

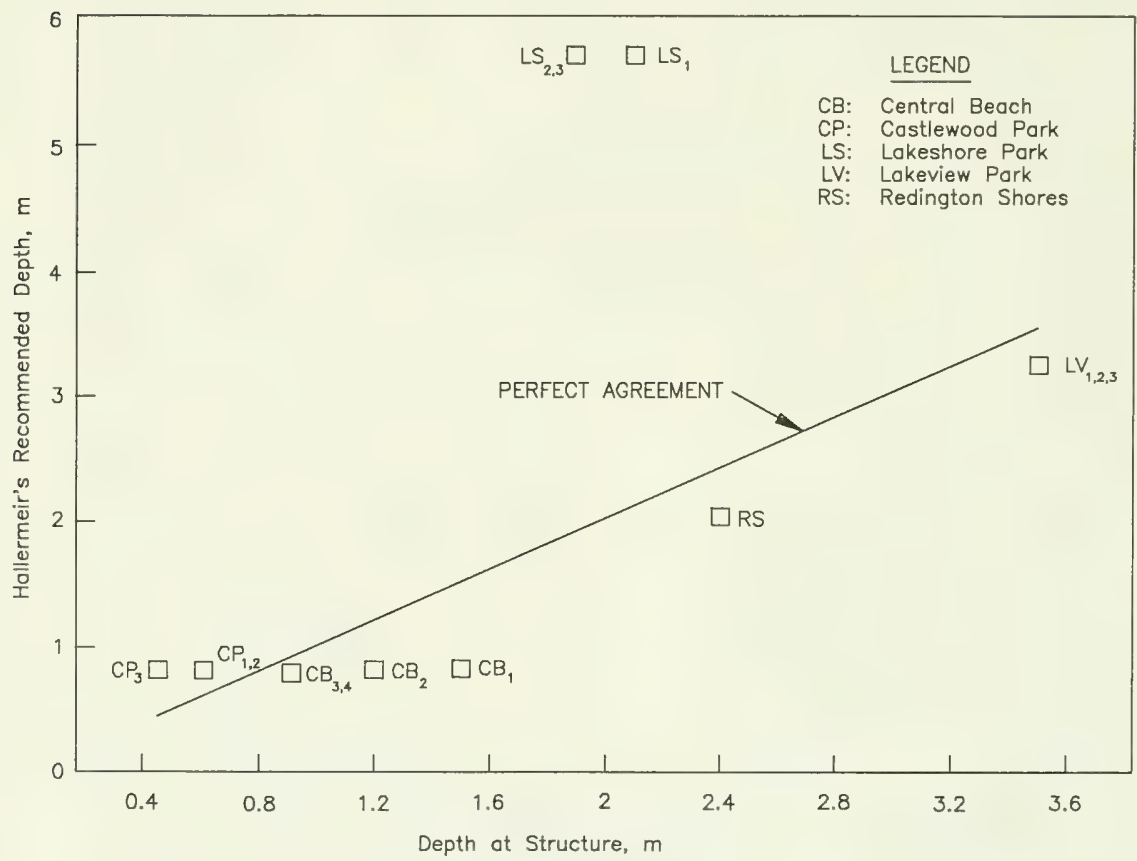

Figure 15. Evaluation of Hallermeier's (1986) relationship for structure design depth 


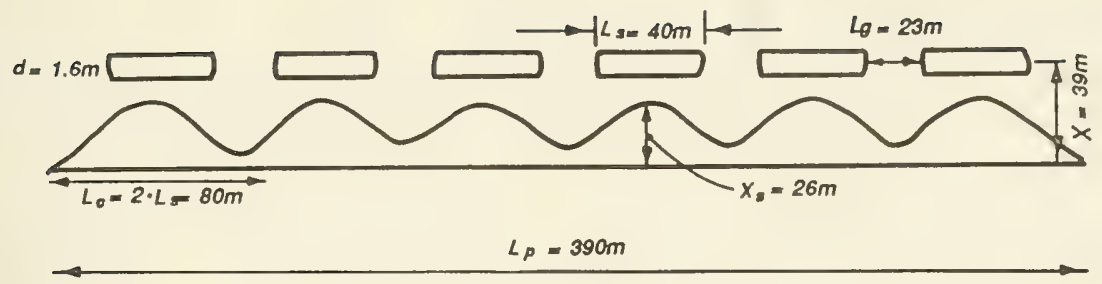

Figure 16. Lakeview Park project parameters as designed with JMC method (Rosati and Truitt 1990)

from the Diffraction Energy Method (Walker, Clark, Pope 1980; see discussion in Part II) (Figure 17). The four example problems conducted by Rosati and Truitt (1990) indicated that, for the site parameters evaluated, use of the JMC design tended to result in "more numerous, shorter length segments with a decreased gap width. . structures are placed closer to shore than observed in US projects."

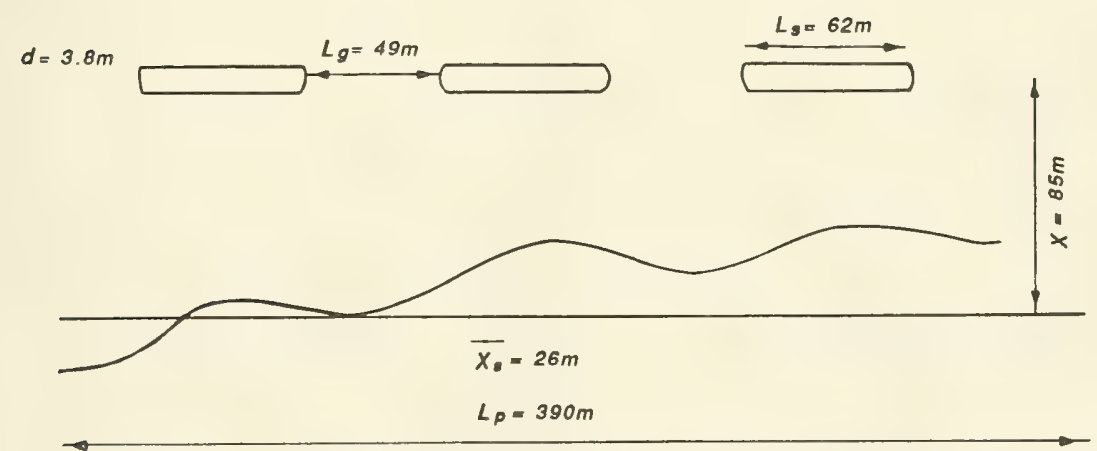

Figure 17. Lakeview Park project as constructed (Diffraction Energy Method) (Rosati and Truitt 1990) 


\section{Comparison of methods}

52. Using the design relationships presented in Part II, the Lakeview Park project has been used to intercompare relationships and further assess their validity. This project was chosen for use because it is representative of US projects, has been successful in protecting the project beach, and has already been designed using the JMC and Diffraction Energy Methods. Recommended project parameters using Toyoshima's $(1972,1974)$ median-depth system were also calculated for comparison. Linear wave theory was used to bring deepwater waves to the structure, and the structure depth using Toyoshima's method was the same as the as-constructed depth. The various design parameters resulting from each method are presented in Table 2.

Table 2

Lakeview Park Structural Parameters Corresponding to Design Method

\begin{tabular}{lccccc}
\hline \multicolumn{1}{c}{ Method } & $\frac{L_{\mathrm{s}}, \mathrm{m}}{76}$ & $\frac{L_{\mathrm{g}}, \mathrm{m}}{49}$ & $\frac{X, \mathrm{~m}}{73}$ & $\frac{d, \mathrm{~m}}{3.5}$ & $\frac{L_{\mathrm{s}} / X}{1.04}$ \\
$\begin{array}{l}\text { Diffraction } \\
\begin{array}{l}\text { Energy } \\
\text { (as constructed) }\end{array}\end{array}$ & 40 & 23 & 39 & 1.6 & 1.03 \\
$\begin{array}{l}\text { JMC } \\
\begin{array}{l}\text { Toyoshima's Median- } \\
\text { Depth System }\end{array}\end{array}$ & 60 & 24 & $18-40$ & 3.5 & $1-3.3$ \\
\hline
\end{tabular}

53. The JMC method resulted in a smaller structure length, gap distance, and distance offshore from the original shoreline as compared with the as-constructed parameters. Toyoshima's median-depth system resulted in a larger segment length and gap distance than the JMC method, but distance offshore was equal to or less than the other two methods. The range in recommended structure distance offshore is quite large using Toyoshima's method. Using values of the structure length-to-distance offshore ratios for each method with the predictive relationships discussed in Part II (also illustrated in Figure 10), the most likely morphological response corresponding to each method can be predicted. The majority of the relationships indicate that the most likely beach response for all three methods would be tombolos. However, the morphological response in the prototype is salients. 
54. Suh and Dalrymple's relationship predicts salient lengths $X_{\mathrm{s}}$ (Equation 42) equal to 72 and $39 \mathrm{~m}$ using project parameters obtained from the Diffraction Energy and JMC methods, respectively. These values differ from the design salient length $\left(X_{\mathrm{S}}=26 \mathrm{~m}\right)$ used for both the Diffraction Energy and JMC methods. However, using an average distance offshore for Toyoshima's method $X=29 \mathrm{~m}$ results in a predicted salient length equal to $24 \mathrm{~m}$, very close to the prototype response.

55. Harris and Herbich's (1986) relationship for salient volume (Equation 45) predicted the largest volume of salient accretion if structural parameters obtained from the Diffraction Energy method $\left(4,200 \mathrm{~m}^{3}\right.$ ) were used, followed by Toyoshima's median-depth system $\left(3,300 \mathrm{~m}^{3}\right.$ ) (using an average distance offshore equal to $29 \mathrm{~m}$ ), then by the JMC method $\left(540 \mathrm{~m}^{3}\right)$. Since the values of $L_{g} / X$ are less than or approximately equal to 0.8 , Seiji, Uda, and Tanaka's (1987) ranges to predict gap erosion (Equations 30 through 32) indicate that only a slight possibility for gap erosion exists for all sets of structural parameters. 
56. An intercomparison of empirical design methods and predictive relationships such as presented in Part III may be useful in lending validity to certain design tools. However, it is difficult to make broad generalizations about the reliability of empirical methods. The inherent simplicity of the empirical methods evaluated herein and the lack of a large prototype database tended to result in widely varying predictions for most design relationships. As with any research study, more prototype, numerical, and physical model data sets would greatly increase knowledge and predictive abilities.

57. However, several design methods and relationships were shown to be useful predictors, if their limitations are realized throughout the design process. Suh and Dalrymple's (1987) relationship predicting salient length in the on-offshore direction tended to overpredict the salient excursion $(R=0.67)$, but was a very good predictor for pocket-beach type projects with tombolo formation. Dividing Harris and Herbich's (1986) volume relationship by Nir's (1982) salient/tombolo thickness relationship gave a prediction of the salient/tombolo area. The correlation between measured (assumed to have a triangular shape) and predicted area was weak $(R=0.18)$, but a trend was observed. Seiji, Uda, and Tanaka's limit for "no gap erosion" was shown to be a fairly good predictor. Berenguer and Enriquez' (1988) and Ahren's relationships to predict gap erosion for pocket beaches, developed from pocket beach data in Spain, were poor indicators of actual gap erosion for US headland projects $(R=-0.99, R=-0.24$, respectively). Hallermeier's (1983) recommended depth for breakwater projects was shown to correlate well to actual project depth for all but one project (overall $R=0.55$ ).

58. The success of the Lakeview Park project lends validity to the method used to design it, the Diffraction Energy Method. A comparison of Lakeview Park as-constructed project parameters to those recommended by the JMC method and Toyoshima's median-depth system was conducted. Both the latter two methods resulted in smaller segment lengths and gap distances than the asconstructed project. The structures were also positioned closer to shore than indicated by the Diffraction Energy Method.

59. As with any design procedure, limitations of any empirical method 
must be realized throughout the design process. Empirical methods shown to be reasonable predictors herein can be useful as simple, inexpensive indicators of likely prototype response. Ideally, after a desk-top empirical design, the proposed project should be further evaluated with numerical and physical models, followed by a prototype test if time and funding allow. 


\section{REFERENCES}

Adachi, S., Sawaragi, T., and Ogo, A. 1959. "The Effects of Coastal Structures on the Littoral Sand Drifts," Coastal Engineering in Japan, Vol 2, Japanese Society of Civil Engineers, pp 85-98.

Ahrens, J. P., and Cox, J. "Design and Performance of Reef Breakwaters," submitted to Journal of Coastal Research, in press.

Berenguer, J., and Enriquez, J. 1988. "Design of Pocket Beaches: The Spanish Case," Proceedings, 21st International Coastal Engineering Conference, pp 1411-1425.

Chew, S. Y., Wong, P. P., and Chin, K. K. 1974. "Beach Development Between Headland Breakwaters," Proceedings, 14th International Conference on Coastal Engineering, June 24-28, Copenhagen, Denmark, American Society of Civil Engineers, pp 1399-1418.

Danish Hydraulic Institute. 1988. "Offshore Breakwaters, Negombo: Report on Physical Model Tests," Report prepared for Coast Conservation Department of Sri Lanka, Chapters 1-4.

Dally, W. R., and Pope, J. 1986. "Detached Breakwaters for Shore Protection," Technical Report CERC-86-1, US Army Engineer Waterways Experiment Station, Vicksburg, MS.

Goldsmith, V., and Sofer, S. 1983. "Wave Climatology of the Southeastern Mediterranean: An Integrated Approach," Israel Journal of Earth Science, Vol 32, pp 1-51.

Gorecki, R. J., and Pope, J. "Coastal Geologic and Engineering History of Presque Isle, Peninsula, Pennsylvania," Miscellaneous Paper in preparation, US Army Engineer Waterways Experiment Station, Vicksburg, MS.

Gourlay, M. R. 1981. "Beach Processes in the Vicinity of Offshore Breakwaters," Proceedings, Fifth Australian Conference on Coastal and Ocean Engineering, Perth. Australia, pp 129-134.

Hallermeier, R. J. 1983. "Sand Transport Limits in Coastal Structure Designs," Proceedings, Coastal Structures '83. March 9-11. Arlington, Virginia, American Society of Civil Engineers, pp 703-716.

Hanson, H., and Kraus, N. C. 1989. "GENESIS: Generalized Model for Simulating Shoreline Change; Report 1, Technical Reference," Technical Report CERC-89-19, US Army Engineer Waterways Experiment Station, Vicksburg, MS .

Harris, M. M., and Herbich, J. B. 1986. "Effects of Breakwater Spacing on Sand Entrapment," Journal of Hydraulic Research, Vol 24, No. 5, pp 347-357. 
Inman, L. D., and Frautschy, J. D. 1966. "Littoral Processes and the Development of Shorelines," Proceedings, Coastal Engineering. Santa Barbara, CA, pp 511-536.

Japanese Ministry of Construction. 1986. "Handbook of offshore Breakwater Design," River Bureau of the Ministry of Construction, Japanese Government, translated from Japanese for the Coastal Engineering Research Center.

Laustrup, C. 1988. "Erosion Control with Breakwaters and Beach Nourishment," Journal of Coastal Research, Vol 4, No. 4, pp 677-685.

Lesnick, J. R. 1979. "An Annotated Bibliography on Detached Breakwaters and Artificial Headlands," CERC Miscellaneous Report No. 79-1, US Army Engineer Waterways Experiment Station, Vicksburg, MS.

Nir, Y. 1976 (Mar). "Detached Breakwaters, Groynes and Artificial Structures on the Mediterranean Shore and Their Influence on the Structures of the Israeli Shore," Report No. 3, 76/2, Ministry of Industry and Commerce, Geological Institute, Marine Geology Section, Jerusalem (in Hebrew).

Nir, Y. 1982. "Offshore Artificial Structures and Their Influence on the Israel and Sinai Mediterranean Beaches," Proceedings, 18th International Coastal Engineering Conference, American Society of Civil Engineers, pp 1837-1856.

Noble, R. M. 1978. "Coastal Structures' Effects on Shorelines," Proceedings, 17 th International Coastal Engineering Conference, Sydney, Australia, American Society of Civil Engineers, pp 2069-2085.

Noda, H. 1984. "Depositional Effects of Offshore Breakwater due to OnshoreOffshore Sediment Movement," Proceedings, 19th International Coastal Engineering Conference, September 3-7. Houston, Texas, American Society of Civil Engineers, pp 2009-2025.

Pope, J. 1989. "Role of Breakwaters in Beach Erosion Control," Proceedings, Florida Shore and Beach Preservation Association Conference, February 22-24. Tampa, Florida, in press.

Pope, J., and Dean, J. L. 1986. "Development of Design Criteria for Segmented Breakwaters," Proceedings, 20th International Coastal Engineering Conference, November 9-14. Taipei, Taiwan, American Society of Civil Engineers, pp 2144-2158.

Rosen, D. S., and Vadja, M. 1982. "Sedimentological Influences of Detached Breakwaters," Proceedings, 18th International Coastal Engineering Conference, American Society of Civil Engineers, pp 1930-1949.

Rosati, J. D., and Truitt, C. L. 1990. "An Alternative Design Approach for Detached Breakwater Projects," Miscellaneous Paper in preparation, US Army Engineer Waterways Experiment Station, Vicksburg, MS. 
Sauvage de St. Mark, M. G., and Vincent, M. G. 1955. "Transport Littora1 Formation de Fleches et de Tombolos," Proceedings, 5th International Conference on Coastal Engineering. Grenoble, American Society of Civil Engineers, pp 296-328.

Seiji, M., Uda, T., and Tanaka, S. 1987. "Statistical Study on the Effect and Stability of Detached Breakwaters," Coastal Engineering in Japan, Vol 30 , No. 1 , pp 131-141.

Shinohara, K., and Tsubaki, T. 1967. "Model Study on the Change of Shoreline of Sandy Beach by the Offshore Breakwater," Proceedings, 10th International Conference on Coastal Engineering. Tokyo, Japan, American Society of Civil Engineers, pp 550-563.

Shore Protection Manual. 1984. 4th ed., 2 Vols, US Army Engineer Waterways Experiment Station, Coastal Engineering Research Center, US Government Printing office, Washington, DC.

Silvester, R., and Ho, S. 1972. "Use of Crenulate Shaped Bays to Stabilize Coasts," Proceedings, 13th International Conference on Coastal Engineering, July 10-14, Vancouver, B.C., Canada. American Society of Civil Engineers, pp 1347-1365.

Sonu, C. J., and Warwar, J. F. 1987. "Evolution of Sediment Budgets in the Lee of a Detached Breakwater," Proceedings, Coastal Sediments '87, May 12-14. New Orleans, Louisiana, American Society of Civil Engineers, pp 1361-1368.

Suh, K., and Dalrymple, R. A. 1987 (Mar). "Offshore Breakwaters in Laboratory and Field," Journal. Waterway, Port, Coastal, and Ocean Engineering, Vol 113, No. 2, pp 105-121.

Toyoshima, 0. 1972. Coastal Engineering for Practicing Engineers-Beach Erosion, Morikita Publishing Co., Tokyo, Japan. (English translation available through the Coastal Engineering Research Center, US Army Engineer Waterways Experiment Station, Vicksburg, MS, for Chapter 8 on "Offshore Breakwaters," pP 227-317).

1974. "Design of a Detached Breakwater System," Proceedings, 14th International Conference on Coastal Engineering, June 24-28. Copenhagen, Denmark, pp 1419-1431.

1976. "Changes of Sea Bed due to Detached Breakwaters," Proceedings, 15th International Conference on Coastal Engineering, July 11-17. Honolulu, Hawaii, pp 1572-1589.

1982. "Variation of Foreshore due to Detached Breakwaters," Proceedings, 18th International Conference on Coastal Engineering, American Society of Civil Engineers, pp 1873-1892.

US Army Engineer District, Buffalo. 1975. "Lakeview Park General Design Memorandum, Phase II, Project Design," Buffalo, NY. 
Walker, J. R., Clark, D., and Pope, J. 1980. "A Detached Breakwater System for Shore Protection," Proceedings, 17th International Coastal Engineering Conference, Sydney, Australia, pp 1968-1987. 



\section{APPENDIX A: NOTATION}

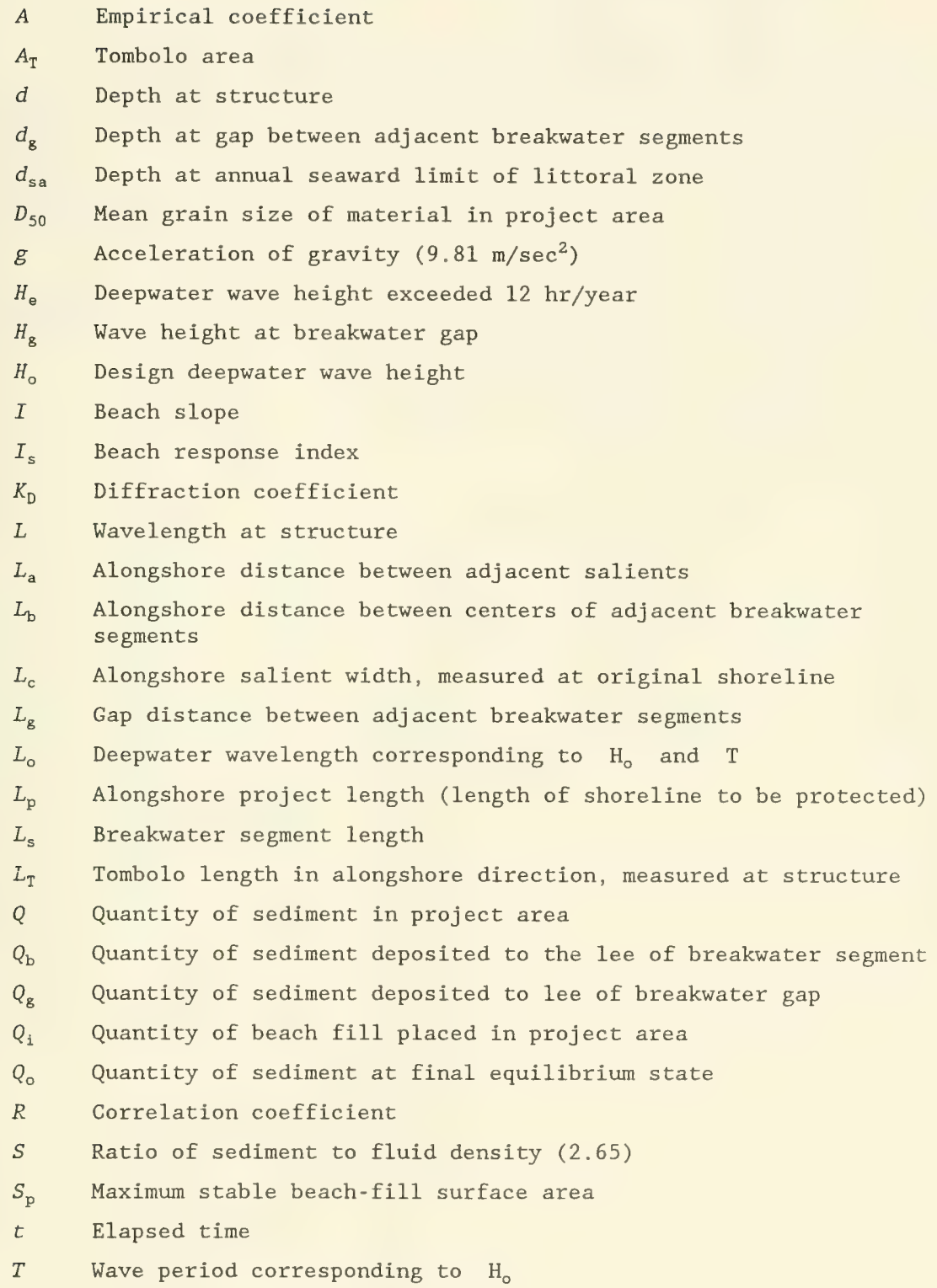


$T_{\mathbf{e}} \quad$ Wave period corresponding to $\mathrm{H}_{\mathrm{e}}$

$V \quad$ Sediment fall speed

$X \quad$ Breakwater segment distance from original shoreline

$X_{\mathrm{b}} \quad$ Distance from original shoreline to mean breaker line

$X_{\mathrm{g}} \quad$ Erosion/accretion opposite gap, measured from original shoreline

$X_{\mathrm{gi}} \quad$ Erosion/accretion opposite gap, measured from initial beach-fill shoreline

$X_{1} \quad$ Breakwater segment distance from initial beach-fill shoreline

$X_{\mathrm{s}} \quad$ Salient/tombolo length in on-offshore direction measured from original shoreline

$X_{\text {si }}$ Salient/tombolo length in on-offshore direction measured from initial beach-fill shoreline

$z_{\mathrm{s}} \quad$ Average sand thickness in tombolo/salient

B Predominant angle of wave approach 




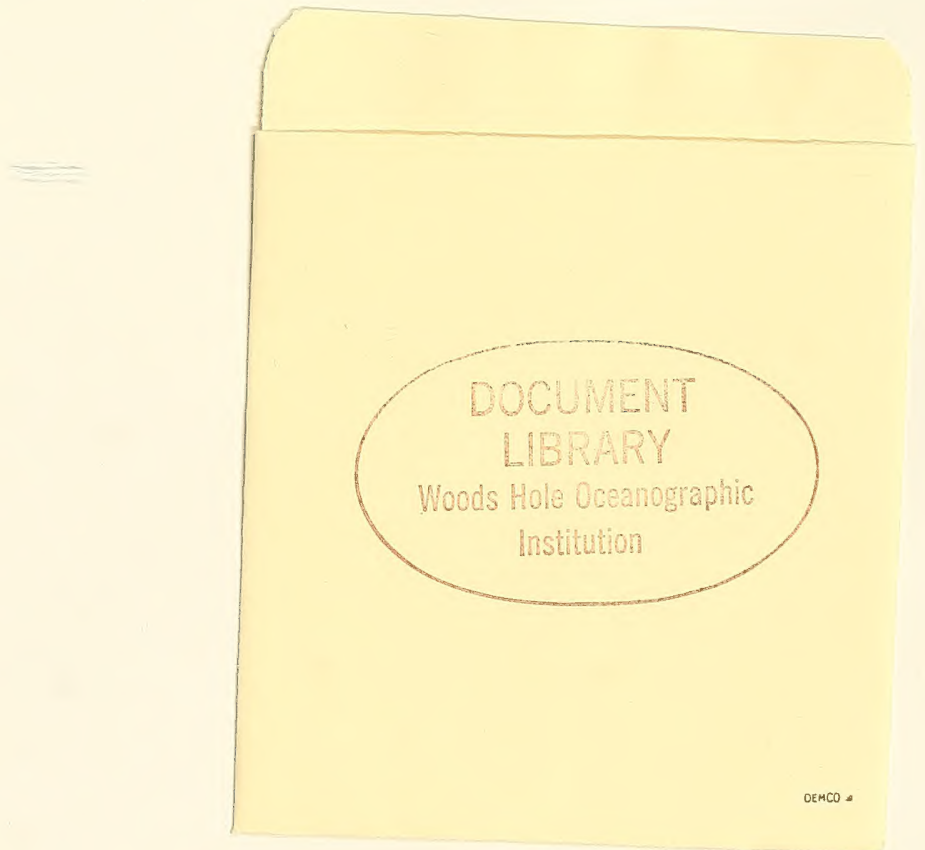




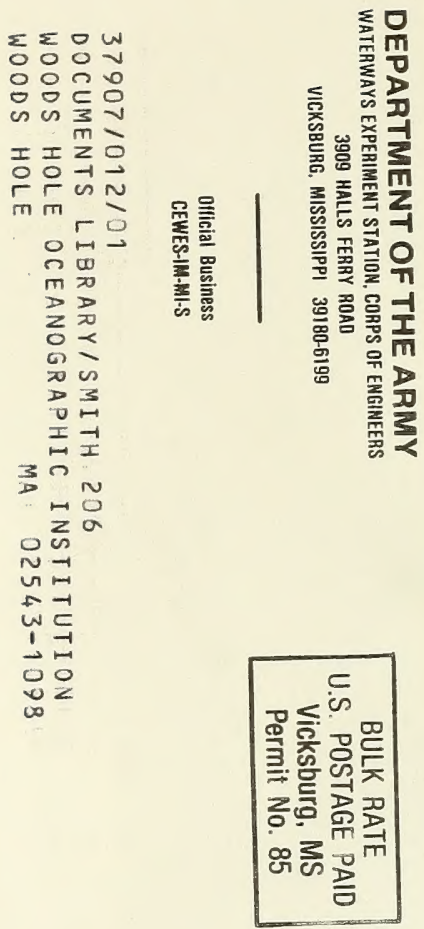

